Article

\title{
Assessing Effectiveness of Humanitarian Activities against COVID-19 Disruption: The Role of Blockchain-Enabled Digital Humanitarian Network (BT-DHN)
}

\author{
Sudhanshu Joshi ${ }^{1,2}$ D, Manu Sharma ${ }^{3,4}$, Rashmi Prava Das ${ }^{5}$, Kamalakanta Muduli ${ }^{6,7}$, , Rakesh Raut $^{8}$, \\ B. E. Narkhede ${ }^{9}$ (D) Himanshu Shee ${ }^{10}$ (D) and Abhishek Misra ${ }^{3}$
}

1 Operations and Supply Chain Management Area, School of Management, Doon University, Dehradun 248001, India; sudhanshujoshi@doonuniversity.ac.in

2 Faculty of Engineering \& Information Technology, University of Technology Sydney, Sidney 2007, Australia

3 Department of Management Studies, Graphic Era Deemed to be University, Dehradun 248002, India; sharmamanu53@gmail.com (M.S.); abhishekmisra@geu.ac.in (A.M.)

4 Guildhall School of Business and Law, London Metropolitan University, London EC2M 6SQ, UK

5 Computer Science Department, CV Raman Global University, Bhubaneswar 752054, India; 2101070068@cgu-odisha.ac.in

6 Department of Mechanical Engineering, Papua New Guinea University of Technology, Lae 411, Papua New Guinea

7 Department of Mechanical Engineering, CV Raman Global University, Bhubaneswar 752054, India

8 Operations \& Supply Chain Management, National Institute of Industrial Engineering (NITIE), Mumbai 400087, India; rraut@nitie.ac.in

9 Industrial Engineering \& Manufacturing Systems, National Institute of Industrial Engineering (NITIE), Mumbai 400087, India; benarkhede@nitie.ac.in

check for updates

Citation: Joshi, S.; Sharma, M.; Das, R.P.; Muduli, K.; Raut, R.; Narkhede, B.E.; Shee, H.; Misra, A. Assessing Effectiveness of Humanitarian Activities against COVID-19 Disruption: The Role of Blockchain-Enabled Digital Humanitarian Network (BT-DHN) Sustainability 2022, 14, 1904. https://doi.org/10.3390/su14031904 Academic Editor: Roberto Cerchione

Received: 15 December 2021 Accepted: 25 January 2022 Published: 7 February 2022 Publisher's Note: MDPI stays neutral with regard to jurisdictional claims in published maps and institutional affiliations.

Copyright: (C) 2022 by the authors. Licensee MDPI, Basel, Switzerland. This article is an open access article distributed under the terms and conditions of the Creative Commons Attribution (CC BY) license (https:// creativecommons.org/licenses/by/ $4.0 /)$.
10 Supply Chain \& Logistics Management, College of Business, Victoria University, Melbourne 8001, Australia; Himanshu.Shee@vu.edu.au

* Correspondence: kamalakantam@gmail.com; Tel.: +675-74272286

\begin{abstract}
The COVID-19 pandemic has affected more than 214 countries across the world, disrupting the supply of essential commodities. As the pandemic has spread, humanitarian activities (HAs) have attempted to manage the various situation but appear ineffective due to lack of collaboration and information sharing, inability to respond towards disruption, etc. This study aims to determine and provide insights into the critical factors that may enhance the effectiveness of HAs during the pandemic. A systematic literature review was undertaken to explore critical factors and validated by experts using the fuzzy-Delphi method. These were further assessed to identify the cause-and-effect relationship by means of the fuzzy decision-making trial and laboratory (DEMATEL) method. The results show that building a blockchain-enabled digital humanitarian network (BT-DHN) is the most significant factor during the pandemic. The use of digital platforms for sharing real-time information enhances the effectiveness of HAs. This study offers stakeholders, policymakers, and decision-makers the opportunity to consider these factors in strategic planning to deal with pandemic disruption.
\end{abstract}

Keywords: humanitarian activities (HAs); humanitarian organization (HO); pandemic disruption; COVID-19; blockchain-enabled digital humanitarian networks (BT-DHN)

\section{Introduction}

Natural disasters such as earthquakes, tornados, wildfires, floods, etc., inevitably disrupt supply chains regionally or globally [1]. The disruptions are seen in any form: it could be the shortage of materials, a temporary peak in demand of essential items that stimulates fear of resource scarcity, an uncontrollable environment, or many other such undesirable events. Humanitarian supply chains (HSCs) appear to hastily manage such disruptions and uncertainties [2,3]. However, developing an HSC is often more complex when compared to the general commercial supply chain [4]. The disruption caused by the virus outbreaks such 
as coronavirus (2019-nCoV) in China, the Zika virus, avian influenza A (H7N9), and Ebola virus (Zaire strain) in West Africa created a threat to human health and safety that questions the readiness / preparedness of any organization in meeting such emergency. The rise of the supply of 'essential items' (items of daily needs) and medical equipment (personal protection equipment, surgical masks, and ventilators) faces unprecedented demand for a much higher volume in comparison to the pre-COVID-19 situation [5,6]. The imbalance of demand and supply and the threat to human lives warrants humanitarian activities that offer long-term and short-term aid to the affected population. We define humanitarian activities (HAs) as the humanitarian emergency support offered to rescue any vulnerable individual or a group of individuals in a community by a collaborative effort of humanitarian organizations and their stakeholders. In an emergency, organizations need enhanced operational efficiencies and effective logistics services for vulnerable communities. These organizations, henceforth called humanitarian organizations (HOs), are required to be agile and adaptive to manage the emergency $[7,8]$. The role of digital technologies, including blockchain, in humanitarian activities is highly significant during a time of emergency [9,10]. BT are useful in the designing and development of the digital humanitarian network. Thus, the BT-enabled DHNs can bring more clarity and accessibility to actors and flawless movement of disaster aids and information across the supply chains [11-13]. Humanitarian aid usually has a linear flow of supplies to the affected areas, especially to regions where the need is higher [14]. During COVID-19, the commercial supply chains deliver the needed supplies. However, humanitarian aids require a vast network and resource prediction until it is needed [15-18]. This acts as a limiting factor for HOs as multiple stakeholders are present in the supply chain. The development of humanitarian strategies and continuous assessment of humanitarian abilities of the cross-sector partners is important for sourcing essentials and strategic supplies $[19,20]$. The supply chain disruptions can be mitigated using a few operational strategies, including maintaining safety stock or exclusive supplies of healthcare products such as masks, hand sanitizers, protective gear, and ventilators from alternative sources through mobilization of resources [21]. Based on experiences from the past, humanitarian activities should include initiating the action plan and its implementation in cost-effective ways to ensure the flow of goods and services to a vulnerable group of people [22,23]. Therefore, creating a responsive portfolio of customized humanitarian services has become a major concern and topic of discussion by global disaster planners, humanitarian partners, researchers, and practitioners, including the World Health Organization (WHO). Since the 1990s, the WHO has highlighted the need for sustainable partnerships among various stakeholders (including governments, researchers, nonprofit organizations, private firms, and R\&D entities), contributing to a variety of HAs in response to disaster mitigation [24,25]. The COVID-19 pandemic is considered the worst crisis since the Second World War [26,27]. As defined by the International Federation of Red Cross and Red Crescent Societies, COVID-19 is categorized as a natural hazard [28]. Disaster risk management has a relationship with the type of disaster, vulnerability, and exposure, as explained in this formula: risk = disaster*vulnerability*exposure $[29,30]$. For reducing risks, besides disaster prevention, it is required to plan and reduce vulnerability and exposure. Thus, the operational effectiveness in the pandemic situation cannot be seen as a whole; it needs to be broken down into meaningful and efficient sub-systems to measure its effectiveness [31-33]. However, research in this space is quite limited. Table 1 demonstrate the searching pattern from the previous research, the results shows most studies are done using single success factors. However, validation of those success factors using the fuzzy-Delphi method and subsequently assessing through cause-and-effect relationship using the fuzzy decision-making trial and laboratory (DEMATEL) method is new in this study. The present research, therefore, aims to evaluate the HAs in the context of a pandemic situation and to identify these critical factors for their efficiencies and effectiveness. The following research questions are developed to answer this objective.

RQ1. What critical factors contribute to the development of effective HAs in COVID-19? RQ2. What interrelationship and hierarchy exist between these critical factors (CFs)? 
RQ3. To what extent do these critical factors have cause-and-effect interrelationships?

The outcomes of the study will facilitate the disaster planners and strategists to guide their humanitarian supply chain to effectively implement HAs during the pandemic. The study contributes a set of HAs in context to the COVID-19 pandemic. Methodologically, this study employed a systematic literature review followed by the assessment of factors using fuzzy-DEMATEL. The paper is organized as shown below. Section 2 captures the various critical factors based on a systematic literature review. Section 3 describes the research methodology undertaken in the study. Section 4 gives detailed elaboration of the fuzzy-Delphi and fuzzy-DEMATEL methods. Section 4 elaborates the application of methods to validation and cause-and-effect interrelationships computations. Section 5 presents the discussion of the findings of the study. Section 6 highlights the implications, followed by the conclusion and limitations in Section 7.

Table 1. Search criteria.

\begin{tabular}{cccccc}
\hline Search Terms & $\begin{array}{c}\text { Initial } \\
\text { Search }\end{array}$ & $\begin{array}{c}\text { First } \\
\text { Screening }\end{array}$ & $\begin{array}{c}\text { Second } \\
\text { Screening }\end{array}$ & $\begin{array}{c}\text { Third } \\
\text { Screening }\end{array}$ & $\begin{array}{c}\text { Fourth } \\
\text { Screening }\end{array}$ \\
\hline $\begin{array}{c}\text { "Humanitarian" AND } \\
\text { "Pandemic" }\end{array}$ & 15 & 11 & 9 & 8 & 5 \\
\hline $\begin{array}{c}\text { "Humanitarian } \\
\text { operations" AND } \\
\text { "Pandemic" }\end{array}$ & 21 & 12 & 11 & 10 & 6 \\
\hline $\begin{array}{c}\text { Humanitarian } \\
\text { Logistics" AND } \\
\text { "COVID-19" }\end{array}$ & 25 & 20 & 18 & 15 & 12 \\
\hline $\begin{array}{c}\text { Critical Success } \\
\text { Factors" AND }\end{array}$ & 27 & 10 & 9 & 5 \\
\hline Humanitarian" & Total articles & & 28 \\
\hline
\end{tabular}

\section{Literature}

A systematic literature review was undertaken to search articles published from 2000 to 2020. Table 1 presents the search criteria used in the literature review.

The first search resulted in 88 articles. After removing the duplicates, it came down to 54; narrowing down only to journal articles resulted in 48 articles, exclusion of unrelated articles retained 42 articles, and finally, abstract checking resulted in 28 papers. From the selected papers, factors were identified. This followed an expert survey where each expert thoroughly read the description of these critical factors in the questionnaire and evaluated them according to their significance in the enhancement of organizational effectiveness. The detailed elaboration of the factors of HAs to enhance operational activities during a pandemic is discussed in the following section.

\section{Humanitarian Activities (HAs) in Enhancing Operational Effectiveness during the Pandemic}

Developing a sustainable humanitarian supply chain (HSC) for managing disasters/emergencies can be viewed as an extension of the traditional supply chain $[34,35]$. Thus, sustainable HSCs have evolved as a specialized discipline with a focus on social sustainability [36,37]. Various parties (including NGOs, local and regional relief organizations, government agencies, HOs, and beneficiaries) and other stakeholders from the corporate sector comprise a centralized or a decentralized HSC structure [38,39] that aims to relieve the masses at risk. Otherwise, a single actor individually may not have sufficient resources to respond effectively to major disasters, including COVID-19 [40-42]. HAs play a critical role in a disaster. Coordination among humanitarian parties/actors can strengthen and enhance the outcomes through resource and information sharing, decision-making, and conducting joint-field surveys or cluster-based services towards social needs [43-45]. 
Figure 1 illustrates the conceptual framework on critical factors of HAs influencing operational effectiveness of HOs. These HAs improved resilience through vertical and horizontal coordination among the actors [46-49]. In the light of blockchain technology, the effectiveness of HSC results in a smooth flow of suppliers, information, and resources to the beneficiaries and can be measured in terms of response time by using the common elements of supply chain philosophy: "delivery of the right goods, at the right time, to the right place, and to the right set of people" [50]. Thus, a blockchain-driven HSC can be simply defined as a traceable system available to all stakeholders of HSC for effective roles and responsibility of the disaster migration and effective humanitarian activities [51-53].

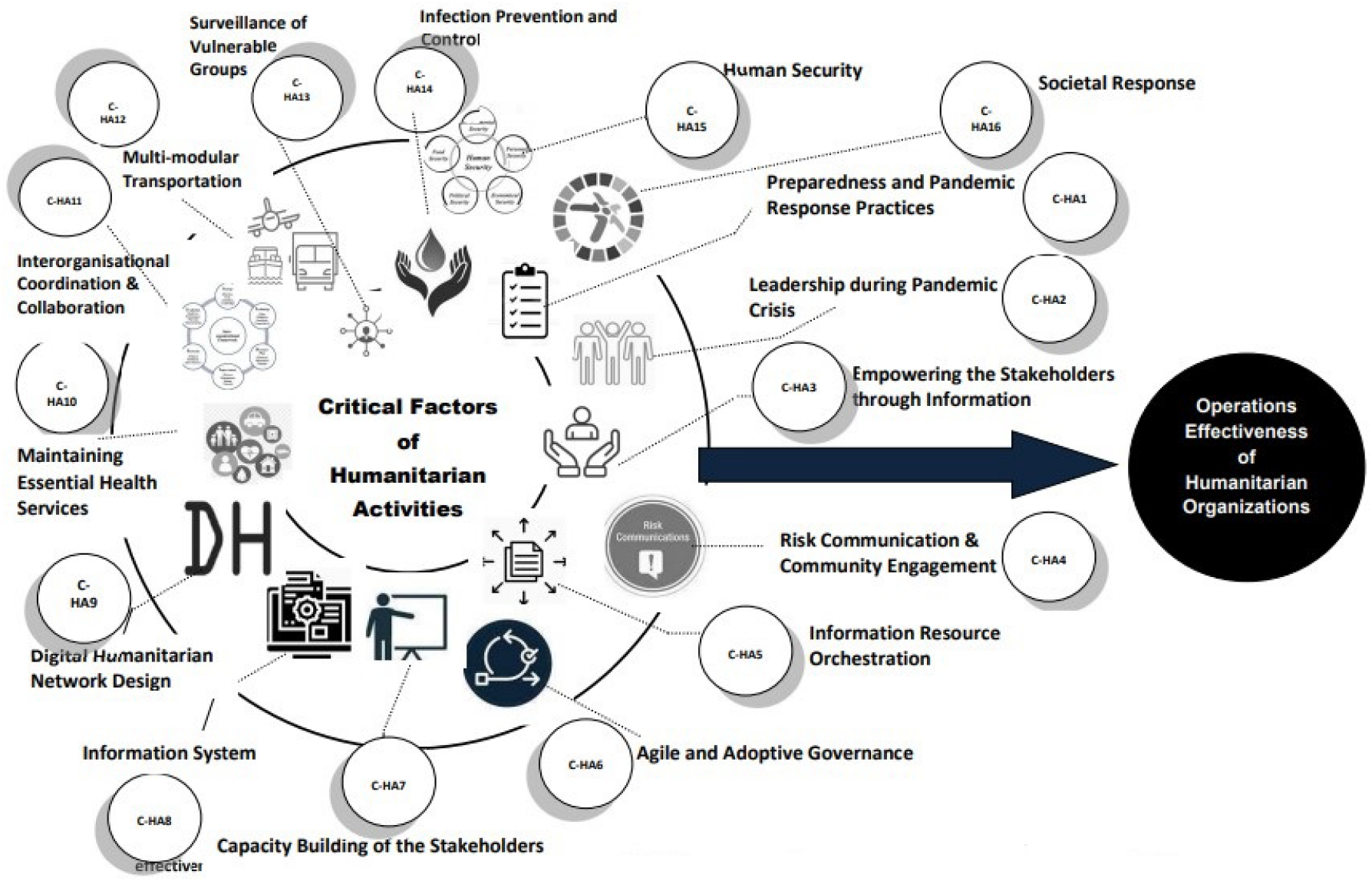

Figure 1. Conceptual framework of critical factors of humanitarian activities influencing humanitarian operations (Source: Authors).

The HAs also result in the development of local and regional infrastructure. Hence, a successful HSC management through HAs thrives to achieve a supply of "essential items" and help in mass evacuation of the community affected by disaster $[54,55]$ through a process of cost-effective flow and storage of goods and materials from the point of origin to the point of consumption for the purpose of meeting the end beneficiary's requirements [56-58]. A typical design of an HSC should be able to manage the available resources efficiently and enable the community to make the right decision by involving local authority through decentralized decision making $[59,60]$. Usage of technology can help HOs to plan capacity, engage resources, and improve demand prediction. The performance of HSC can be measured by its delivery performance (time, coverage, supply chain responsiveness, and cost involved) [61-63]. The COVID-19 is a global outbreak that leads to a sharp and radical shortage of essential supplies (i.e., PPEs, ventilators, protection masks, sanitizers, and hydroxychloroquine) [64-66]. The HSC partners mean to mitigate the global COVID-19 pandemic situation and to ensure critical supplies to aid recipients. An HSC ensures 'line of sight' along with COVID-19 mitigation, prioritized within the wider set of Has [67,68]. 
With the increasing pressure due to the loss of human lives, it is necessary to conduct a study that aims to determine the critical factors of Has $[69,70]$. Multiple stakeholders (parties including the government and private sector) strategically coordinate with each other to perform varieties of HAs to aid recipients [71,72]. Thus, a strategic tie-up has a positive influence on the performance of HSC and increases its sharing capabilities [73-75]. Past literature stressed the feedback mechanism among the stakeholders in a HSCs system for developing a reference model [76-79]. The coordination among humanitarian actors can be increased by cost-effective usage of resources and the involvement of top-level managers in distribution roles [80,81]. Regular interactions between humanitarian actors are essential for the effectiveness of HAs. Effective communication measures to reduce pressure among supply chain actors and optimize the supply of essentials. Usage of ICT ensures the transparency and flawless exchange of information across the HSCs. Additionally, it increases the flexibility, agility, and alignment in emergency decisions. The commitment of humanitarian actors supports the aims of HOs in developing mutual consent towards operational decisions [82]. Effective training of the actors about a pandemic situation helps build capacity to respond more effectively during various disaster situations [83-85]. Various critical success factors are elaborated in Table 2.

Table 2. Critical success factors to enhance operational effectiveness of humanitarian activities.

\begin{tabular}{|c|c|c|}
\hline Critical Factors & Operational Effectiveness during the Pandemic & References \\
\hline $\begin{array}{l}\text { Multi-modal } \\
\text { transportation } \\
\text { (C-HA1) }\end{array}$ & $\begin{array}{c}\text { Usage of multi-modal transportation can connect all } \\
\text { supply nodes, affected areas, and logistics operational } \\
\text { areas. }\end{array}$ & [54] \\
\hline $\begin{array}{l}\text { Leadership during } \\
\text { pandemic crisis } \\
\text { (C-HA2) }\end{array}$ & $\begin{array}{l}\text { Communicating with teams, stakeholders, and } \\
\text { communities during COVID-19 enhances } \\
\text { transparency, demonstrates vulnerability, and builds } \\
\text { resilience among humanitarian organizations. }\end{array}$ & [56] \\
\hline $\begin{array}{l}\text { Empowering the } \\
\text { stakeholders } \\
\text { (C-HA3) }\end{array}$ & $\begin{array}{l}\text { Empowerment of the stakeholders helps the } \\
\text { humanitarian organizations to identify clear vision, } \\
\text { competency, and coordination across all levels. }\end{array}$ & {$[29,38]$} \\
\hline $\begin{array}{l}\text { Risk communication } \\
\text { and community } \\
\text { engagement } \\
\text { (C-HA4) }\end{array}$ & $\begin{array}{l}\text { Risk communication across stakeholders brings } \\
\text { transparency and pro-activeness towards the } \\
\text { pandemic situation. }\end{array}$ & [56] \\
\hline $\begin{array}{l}\text { Information resource } \\
\text { orchestration } \\
\text { (C-HA5) }\end{array}$ & $\begin{array}{l}\text { Adoption of information resource activities and } \\
\text { information behavior activities can meet the need of } \\
\text { humanitarian operations. }\end{array}$ & {$[49,64]$} \\
\hline $\begin{array}{l}\text { Agile and adaptive } \\
\text { governance (C-HA6) }\end{array}$ & $\begin{array}{l}\text { Participation collaboration and governance become } \\
\text { more agile and adaptive during the pandemic. }\end{array}$ & {$[60,61]$} \\
\hline $\begin{array}{c}\text { Information system } \\
\text { (C-HA7) }\end{array}$ & $\begin{array}{c}\text { Information system planning should address } \\
\text { challenges, value generation processes, and resource } \\
\text { base in an effort to improve organizational } \\
\text { performance }\end{array}$ & {$[63,65,86,87]$} \\
\hline $\begin{array}{l}\text { Capacity building of } \\
\text { stakeholders } \\
\text { (C-HA8) }\end{array}$ & $\begin{array}{l}\text { A competency-based teaching approach can improve } \\
\text { the intercultural pandemic training among the } \\
\text { stakeholders who can further improve } \\
\text { interdisciplinary integration, enhancing the overall } \\
\text { operational effectiveness. }\end{array}$ & [57] \\
\hline $\begin{array}{l}\text { Blockchain-enabled } \\
\text { digital humanitarian } \\
\text { network (BT-DHN) } \\
\text { (C-HA9) }\end{array}$ & $\begin{array}{l}\text { Blockchain-enabled digital humanitarian network } \\
\text { (BT-DHN) ensures participative management and } \\
\text { real-time information flow that uses big data for the } \\
\text { humanitarian response for effective relief operations. }\end{array}$ & {$[2,4]$} \\
\hline
\end{tabular}


Table 2. Cont.

\begin{tabular}{|c|c|c|}
\hline Critical Factors & Operational Effectiveness during the Pandemic & References \\
\hline $\begin{array}{l}\text { Maintaining } \\
\text { essential health } \\
\text { services (C-HA10) }\end{array}$ & $\begin{array}{l}\text { Adjust governance and coordination mechanisms to } \\
\text { support timely action for essential health services and } \\
\text { adapt to changing contexts and needs. }\end{array}$ & {$[20,26,52]$} \\
\hline $\begin{array}{l}\text { Inter-organizational } \\
\text { coordination and } \\
\text { collaboration } \\
\text { (C-HA11) }\end{array}$ & $\begin{array}{c}\text { Collaborative planning for responding the pandemic } \\
\text { (through cooperation, interaction, and collaboration } \\
\text { among relief agencies). }\end{array}$ & {$[29,38]$} \\
\hline $\begin{array}{l}\text { Preparedness and } \\
\text { pandemic response } \\
\text { practices (C-HA12) }\end{array}$ & $\begin{array}{l}\text { Preparedness planning and COVID-19 response } \\
\text { practices emerged as the key humanitarian activity } \\
\text { among humanitarian actors. }\end{array}$ & {$[42,46]$} \\
\hline $\begin{array}{l}\text { Surveillance for } \\
\text { vulnerable groups } \\
\text { (C-HA13) }\end{array}$ & $\begin{array}{l}\text { It aims to limit the spread of the pandemic in } \\
\text { vulnerable groups (children, women, and the old-age } \\
\text { population) by rapid detection, isolation, testing, and } \\
\text { management. }\end{array}$ & {$[88,89]$} \\
\hline $\begin{array}{l}\text { Prevention and } \\
\text { control } \\
\text { (C-HA14) }\end{array}$ & $\begin{array}{c}\text { Infection prevention and control (IPC) is the key } \\
\text { humanitarian activity. IPC occupies a unique position } \\
\text { in the field of patient safety and quality universal } \\
\text { health coverage. }\end{array}$ & [3] \\
\hline $\begin{array}{l}\text { Human security } \\
\text { (C-HA15) }\end{array}$ & $\begin{array}{l}\text { It is protecting human life, especially the vulnerable } \\
\text { groups, by involving local government and partners to } \\
\text { increase operational effectiveness. }\end{array}$ & [39] \\
\hline $\begin{array}{l}\text { Societal response } \\
\text { (C-HA16) }\end{array}$ & $\begin{array}{l}\text { It is the collective efforts of humanitarian } \\
\text { organizations, the corporate world, government, and } \\
\text { the community to fight collectively against the } \\
\text { pandemic. Based on the principle of 'Respond, } \\
\text { Recover and Rebuild', the societal response to the } \\
\text { COVID-19 pandemic is a continuous improvement } \\
\text { process. }\end{array}$ & {$[39,40]$} \\
\hline
\end{tabular}

\section{Research Methodology}

In the past literature, quantitative methods used were either probabilistic techniques, statistics, or both. However, they have several limitations that deal with vagueness and issues of scalability. To delimit these issues, the present study has used an applicable and advanced methodology to assess the effectiveness of the humanitarian activities and to simplify their role during COVID-19 disaster management [85-88]. A three-phase study was conducted, as illustrated in Figure 2. During the first phase, the systematic literature review was conducted to identify HAs, followed by the experts' brainstorming session [41,75]. The detail of experts is presented in Section 4. Based on the responses collected from the experts, validation of the HAs was performed using fuzzy-Delphi. In the second phase, the HAs were assessed using the fuzzy-DEMATEL method to establish the cause-and-effect relationship among them. 


\section{Phase I- Study- Gaps, Objectives, and validation of factors}

Step 1: Identify the literature gap and define the objective of the study

Step 2: Identification the critical factors for enhancing operational effectiveness of Humanitarian activities

Step 3: Conducting brainstorming session with selected Experts

Phase II- Fuzzy-DEMATEL analysis to know cause-effect relationship among critical factors

Step 4: Designing Questionnaire for conducting Fuxzy DEMATEL

Step 5: Data Collection

Step 6: Calculate threshold value and construct canse-effect relationship map

Step 7: Results discussion, managerial implications and study impact

Figure 2. Proposed research framework.

The fuzzy-Delphi and fuzzy-DEMATEL methods are elaborated in the subsequent sub-sections.

\subsection{Fuzzy Set Theory}

The decision making in the context of HAs is complex due to the involvement of multiple actors as well as the subjectivity in judgment due to ambiguity in the data and information. Thus, fuzzy theory helps the decision-makers to clarify human responses in the crisp form under imprecise and uncertain situations [89,90]. In a fuzzy set, binary numbers 0 and 1 represent each number in an interval [0,1]. The fuzzy-based analysis can be defined as if ' $X$ ' explains a set of elements and the general component of ' $X$ ' is explained through ' $X$ ' with values $\left(x_{1}, x_{2}, x_{3} \ldots \ldots \ldots x_{n}\right)$. The fuzzy set $C$ for $X$ can be stated as $\left\{\left(x, \mu_{C}(x)\right) \mid x \in X\right\}$. The membership of this fuzzy set $C$ can be defined through $\mu_{C}(x)$.

Let us assume, ' $\mathrm{A}$ ' and ' $\mathrm{B}$ ' are two TFNs and represented as $\mathrm{A}=\left(p_{1}, q_{1}, r_{1}\right)$ and $\mathrm{B}=$ $\left(p_{2}, q_{2}, r_{2}\right)$. The membership function for the TFN $(p, q, r)$ is calculated using the expression provided in Equation (1).

$$
\mu_{\mathrm{C}}(\mathrm{x})=\left\{\begin{array}{c}
0, x \leq p \\
\frac{x-p}{q-p}, x \in[p, q] \\
\frac{x-r}{q-r}, x \in[q, r] \\
0, \text { otherwise }
\end{array}\right\}
$$

Then, the algebraic operations for $\mathrm{A}$ and $\mathrm{B}$ as per the extension principle:

1. $\mathrm{A} \oplus \mathrm{B}:\left(p_{1}, q_{1}, r_{1}\right) \oplus\left(p_{2}, q_{2}, r_{2}\right)=\left(p_{1}+p_{2}, q_{1}+q_{2}, r_{1}+r_{2}\right)$

2. $\mathrm{A} \ominus \mathrm{B}:\left(p_{1}, q_{1}, r_{1}\right) \ominus\left(p_{2}, q_{2}, r_{2}\right)=\left(p_{1}-p_{2}, q_{1}-q_{2}, r_{1}-r_{2}\right)$ 
3. $\mathrm{A} \otimes \mathrm{B}:\left(p_{1}, q_{1}, r_{1}\right) \otimes\left(p_{2}, q_{2}, r_{2}\right) \cong\left(p_{1} p_{2}, q_{1} q_{2}, r_{1} r_{2}\right)$

4. $\quad \Lambda(\mathrm{A} \otimes \mathrm{B}): y \otimes\left(p_{1}, q_{1}, r_{1}\right)=\left(y p_{1}, y q_{1}, y r_{1}\right)$

5. $\mathrm{A} \oslash \mathrm{B}:\left(p_{1}, q_{1}, r_{1}\right) \oslash\left(p_{2}, q_{2}, r_{2}\right) \cong\left(p_{1} / r_{2}, q_{1} / q_{2}, r_{1} / p_{2}\right)$

\subsection{Fuzzy-Delphi Method}

The fuzzy-based Delphi [78] has the capability to capture vagueness in data. Several studies have used this method for measuring firm performance [90], performance of green supply chain management [91], technology selection [92], and logistics [90-92]. This study has applied fuzzy-Delphi to obtain the joint decision making that aims to assess the critical factors for HAs to develop humanitarian supply chains. The process is elaborated in the following steps.

Step 1: It includes the extraction of HAs from the existing literature. The extraction is exhibited in Figure 1.

Step 2: The identified HAs were shared with the experts. With the help of the linguistic scale (Table 3 ), the HAs are evaluated. Assuming fuzzy number $\widetilde{z}_{i j}$ to be the $j^{\text {th }}$ evaluation of barriers of the $i^{\text {th }}$ expert of $n$ experts,

$$
\begin{array}{r}
\widetilde{z}_{i j}=\left(a_{i j}, b_{i j}, c_{i j}\right) \\
\text { for } i=1,2,3, \ldots, n \text { and } j=1,2,3, \ldots, m
\end{array}
$$

Then, the fuzzy weights of barriers $\widetilde{a}_{j}$ are given as follows: $\widetilde{a}_{j}=\left(a_{j}, b_{j}, c_{j}\right)$, where:

$$
\begin{array}{r}
a_{j}=\min \left(a_{i j}\right), \\
b_{j}=\left(\prod_{i=1}^{n}\left(b_{i j}\right)\right)^{1 / n} \\
c_{j}=\max \left(c_{i j}\right), \text { where }, i=1,2, \ldots, n, j=1,2, \ldots m
\end{array}
$$

Step 3: This final step uses mean method $S j$ through Equation (4).

$$
S j=\frac{\left(a_{j}+b_{j}+c_{j}\right)}{3}, j=1,2,3, \ldots m
$$

The evaluation of critical factors is based on the following condition:

a) Acceptance of factor: When the value of $S_{j}$ is greater or equal to the threshold value $(\alpha)$

b) Rejection of the factor: When the value of $S_{j}$ is less than a threshold value $(\alpha)$

Table 3. Scale labeling.

\begin{tabular}{ccc}
\hline Terms for Scale & Number & Linguistic Terms \\
\hline Very influential (VI) & 4 & $(0.75,1.0,1.0)$ \\
\hline High influence (HI) & 3 & $(0.5,0.75,1.0)$ \\
\hline Low influence (LI) & 2 & $(0.25,0.5,0.75)$ \\
\hline Very low influence (VLI) & 1 & $(0,0.25,0.5)$ \\
\hline No influence (NI) & 0 & $(0,0,0.25)$ \\
\hline
\end{tabular}

\subsection{Fuzzy DEMATEL}

In a multi-variable decision making fuzzy and complex supply chain management problem, fuzzy-DEMATEL can be used as an effective tool $[10,51,69,85]$. Broadly, the mathematical process can be explained as follows:

Step 1: Goal setting and criteria identification 
Step 2: Factors identification to evaluate effect between factors using pairwise comparison.

Step 3: Define the fuzzy linguistic scale. Table 3 explains the linguistic terms used in the study.

Step 4: Development of fuzzy direct-relation matrix Zk. Zk $=[Z \mathrm{kij}]$ where $\mathrm{Z}$ is a $\mathrm{n} \times$ $n$ non-negative matrix; $Z i j$ represents the direct impact of factor $i$ on factor $j$, and, when $\mathrm{i}=\mathrm{j}$, the diagonal elements $\mathrm{Zij}=0$.

Step 5: Establishment of the cause-and-effect model: Compute the total-relation matrix $\mathrm{T}$ using the formula in Equation (5), where $\mathrm{n} \times \mathrm{n}$ identity matrix is represented with I. Upper, and lower values are calculated separately

$$
T=D(I-D)^{-1}
$$

Step 6: The cause-and-effect group factors provides the visualization of the complex interrelationships among factors and are highly significant for decisionmakers.

\section{Research Framework}

The methods are applied sequentially as shown in Figure 2. The framework is elaborated as follows:

\subsection{Phase 1: Identification and Validation of Critical Factors for HAs through Brainstorming}

From the literature review, sixteen critical success factors related to HAs were identified. A brainstorming session was conducted online to identify the perception of health officials and humanitarian organizations (NGOs and private healthcare staff). The data were collected through a questionnaire with an additional sheet to include any extra critical factors. A panel of 11 experts with different expertise over 10 years were engaged in the brainstorming session. The details of the experts are given in Table 4.

Table 4. Details of experts.

\begin{tabular}{|c|c|c|c|c|c|}
\hline Expert Code & Designation & Age (Years) & Industry & $\begin{array}{l}\text { Experience } \\
\text { (Years) }\end{array}$ & Expertise \\
\hline E1 & $\begin{array}{l}\text { Healthcare } \\
\text { professional }\end{array}$ & $>45$ & Health care & $>15$ & Patient care \\
\hline E2 & $\begin{array}{l}\text { Healthcare } \\
\text { professional }\end{array}$ & $>45$ & Health care & $>15$ & Patient care \\
\hline E3 & $\begin{array}{c}\text { Disaster } \\
\text { management } \\
\text { expert }\end{array}$ & $>35$ & Healthcare & $>12$ & Healthcare \\
\hline E4 & $\begin{array}{l}\text { Disaster } \\
\text { management } \\
\text { expert }\end{array}$ & $>40$ & Healthcare & $>15$ & Healthcare \\
\hline E5 & $\begin{array}{c}\text { Disaster } \\
\text { management } \\
\text { expert }\end{array}$ & $>40$ & Healthcare & $>15$ & Healthcare \\
\hline E6 & NGO & $>40$ & $\begin{array}{l}\text { Social well } \\
\text { being }\end{array}$ & $>15$ & Societal issue \\
\hline E7 & Manager & $>35$ & Healthcare & $>15$ & Healthcare \\
\hline E8 & $\begin{array}{c}\text { Healthcare } \\
\text { staff }\end{array}$ & $>35$ & Healthcare & $>10$ & Patient care \\
\hline E9 & Professor & $>45$ & $\begin{array}{c}\text { Higher } \\
\text { education }\end{array}$ & $>20$ & Healthcare \\
\hline E10 & Professor & $>45$ & $\begin{array}{c}\text { Higher } \\
\text { education }\end{array}$ & $>20$ & Healthcare \\
\hline E11 & $\begin{array}{l}\text { Healthcare } \\
\text { staff }\end{array}$ & $>35$ & Healthcare & $>10$ & Patient care \\
\hline
\end{tabular}


The responses were collected from the experts based on the linguistic label shown in Table 3. A threshold value was set more than 0.60 for exclusion and inclusion of the factors based on the previous literature. The experts were also asked to include any factor that they feel can influence the HAs during the pandemic. However, the experts did not suggest any change and were satisfied with the factors they were provided. Through the fuzzy-Delphi method, the factors were assessed and validated. Section 3.1 discussed the steps for computing $S j$, and its final values are exhibited in Table 5.

Table 5. Scores for variables were undertaken using fuzzy-Delphi.

\begin{tabular}{|c|c|c|c|c|c|}
\hline S. $N$ & Critical Factors for HAs & $l$ & $m$ & $u$ & $S$ \\
\hline 1 & $\begin{array}{l}\text { Multi-modal transportation } \\
\text { (C-HA1) }\end{array}$ & 0.25 & 0.89 & 1.00 & 0.712 \\
\hline 2 & $\begin{array}{c}\text { Leadership during pandemic } \\
\text { crisis } \\
\text { (C-HA2) }\end{array}$ & 0.25 & 0.80 & 1.00 & 0.682 \\
\hline 3 & $\begin{array}{l}\text { Empowering the stakeholders } \\
\text { through information (C-HA3) }\end{array}$ & 0.25 & 0.84 & 1.00 & 0.697 \\
\hline 4 & $\begin{array}{l}\text { Risk communication and } \\
\text { community engagement } \\
\text { (C-HA4) }\end{array}$ & 0.25 & 0.82 & 1.00 & 0.689 \\
\hline 5 & $\begin{array}{l}\text { Information resource } \\
\text { orchestration } \\
\text { (C-HA5) }\end{array}$ & 0.30 & 0.82 & 1.00 & 0.706 \\
\hline 6 & $\begin{array}{l}\text { Agile and adaptive governance } \\
\text { (C-HA6) }\end{array}$ & 0.25 & 0.75 & 1.00 & 0.667 \\
\hline 7 & Information system (C-HA7) & 0.25 & 0.84 & 1.00 & 0.697 \\
\hline 8 & $\begin{array}{l}\text { Capacity building of } \\
\text { stakeholders (C-HA8) }\end{array}$ & 0.25 & 0.86 & 1.00 & 0.705 \\
\hline 9 & Prevention and control (C-HA9) & 0.25 & 0.82 & 1.00 & 0.689 \\
\hline 10 & $\begin{array}{l}\text { Maintaining essential health } \\
\text { services } \\
\text { (C-HA10) }\end{array}$ & 0.25 & 0.80 & 1.00 & 0.682 \\
\hline 11 & $\begin{array}{c}\text { Inter-organizational } \\
\text { coordination and collaboration } \\
\text { (C-HA11) }\end{array}$ & 0.25 & 0.75 & 1.00 & 0.667 \\
\hline 12 & $\begin{array}{l}\text { Preparedness and pandemic } \\
\text { response practices (C-HA12) }\end{array}$ & 0.25 & 0.80 & 1.00 & 0.682 \\
\hline 13 & $\begin{array}{l}\text { Surveillance for vulnerable } \\
\text { groups } \\
\text { (C-HA13) }\end{array}$ & 0.25 & 0.82 & 1.00 & 0.689 \\
\hline 14 & $\begin{array}{l}\text { Blockchain-enabled digital } \\
\text { humanitarian network } \\
\text { (BT-DHN) design (C-HA14) }\end{array}$ & 0.25 & 0.77 & 1.00 & 0.673 \\
\hline 15 & Human security (C-HA15) & 0.25 & 0.82 & 1.00 & 0.689 \\
\hline 16 & Societal response (C-HA16) & 0.00 & 0.70 & 1.00 & 0.568 \\
\hline
\end{tabular}

The values of $S j$ in Table 5 suggest that all the variables identified from the literature are valid and must be undertaken for the study as all the values are higher than 0.60 .

\subsection{Fuzzy-DEMATEL for Cause-and-Effect Analysis}

The fuzzy-DEMATEL was applied to establish a cause-and-effect relationship among the sixteen critical factors. The factors were assessed on a linguistic scale mentioned 
in Table 3. The normalized fuzzy numbers and total relation matrix derived from the step-by-step process are shown in Table 6.

Table 6. Total normalized direct-relation matrix $(\mathrm{X})$ for $l, m$, and $u$.

\begin{tabular}{|c|c|c|c|c|c|c|c|c|c|c|c|c|c|c|c|c|}
\hline \multicolumn{17}{|c|}{$(l)$} \\
\hline Factors & $\begin{array}{c}\mathrm{C}- \\
\mathrm{HA} 1\end{array}$ & $\begin{array}{c}\text { C- } \\
\text { HA2 }\end{array}$ & $\begin{array}{c}\mathrm{C}- \\
\mathrm{HA} 3\end{array}$ & $\begin{array}{c}\text { C- } \\
\text { HA4 }\end{array}$ & $\begin{array}{c}\text { C- } \\
\text { HA5 }\end{array}$ & $\begin{array}{c}\text { C- } \\
\text { HA6 }\end{array}$ & $\begin{array}{c}\text { C- } \\
\text { HA7 }\end{array}$ & $\begin{array}{c}\text { C- } \\
\text { HA8 }\end{array}$ & $\begin{array}{c}\text { C- } \\
\text { HA9 }\end{array}$ & $\begin{array}{c}\text { C-HA } \\
10\end{array}$ & $\begin{array}{c}\text { C- } \\
\text { HA11 }\end{array}$ & $\begin{array}{c}\text { C- } \\
\text { HA12 }\end{array}$ & $\begin{array}{c}\text { C- } \\
\text { HA13 }\end{array}$ & $\begin{array}{c}\text { C- } \\
\text { HA14 }\end{array}$ & $\begin{array}{c}\text { C- } \\
\text { HA15 }\end{array}$ & $\begin{array}{c}\text { C- } \\
\text { HA16 }\end{array}$ \\
\hline $\begin{array}{c}\text { C- } \\
\text { HA1 }\end{array}$ & 0 & 0.0162 & 0.0129 & 0.0323 & 0.0356 & 0.0209 & 0.0210 & 0.0339 & 0.0387 & 0.0242 & 0.0355 & 0.0355 & 0.0338 & 0.0388 & 0.0355 & 0.0258 \\
\hline $\begin{array}{c}\mathrm{C}- \\
\mathrm{HA} 2\end{array}$ & 0.0209 & 0 & 0.0178 & 0.0501 & 0.0162 & 0.0161 & 0.0193 & 0.0388 & 0.0242 & 0.0194 & 0.0258 & 0.0145 & 0.0210 & 0.0194 & 0.0226 & 0.0340 \\
\hline $\begin{array}{c}\mathrm{C}- \\
\mathrm{HA} 3\end{array}$ & 0.0210 & 0.0194 & 0 & 0.0355 & 0.0323 & 0.0097 & 0.0000 & 0.0388 & 0.0291 & 0.0243 & 0.0323 & 0.0242 & 0.0259 & 0.0275 & 0.0064 & 0.0161 \\
\hline $\begin{array}{c}\text { C- } \\
\text { HA4 }\end{array}$ & 0.0308 & 0.0194 & 0.0000 & 0 & 0.0533 & 0.0178 & 0.0210 & 0.0323 & 0.0226 & 0.0194 & 0.0242 & 0.0178 & 0.0162 & 0.0178 & 0.0226 & 0.0356 \\
\hline $\begin{array}{c}\text { C- } \\
\text { HA5 }\end{array}$ & 0.0370 & 0.0032 & 0.0323 & 0.0000 & 0 & 0.0355 & 0.0178 & 0.0323 & 0.0146 & 0.0323 & 0.0388 & 0.0291 & 0.0275 & 0.0290 & 0.0194 & 0.0356 \\
\hline $\begin{array}{c}\text { C- } \\
\text { HA6 }\end{array}$ & 0.0306 & 0.0243 & 0.0032 & 0.0242 & 0.0355 & 0 & 0.0178 & 0.0355 & 0.0178 & 0.0355 & 0.0307 & 0.0323 & 0.0355 & 0.0211 & 0.0339 & 0.0242 \\
\hline $\begin{array}{c}\text { C- } \\
\text { HA7 }\end{array}$ & 0.0322 & 0.0194 & 0.0242 & 0.0210 & 0.0178 & 0.0161 & 0 & 0.0291 & 0.0178 & 0.0355 & 0.0501 & 0.0323 & 0.0469 & 0.0356 & 0.0371 & 0.0436 \\
\hline $\begin{array}{c}\text { C- } \\
\text { HA8 }\end{array}$ & 0.0258 & 0.0226 & 0.0274 & 0.0162 & 0.0178 & 0.0178 & 0.0355 & 0 & 0.0064 & 0.0064 & 0.0112 & 0.0291 & 0.0469 & 0.0339 & 0.0371 & 0.0372 \\
\hline $\begin{array}{c}\text { C- } \\
\text { HA9 }\end{array}$ & 0.0274 & 0.0177 & 0.0307 & 0.0177 & 0.0194 & 0.0226 & 0.0355 & 0.0355 & 0 & 0.0194 & 0.0340 & 0.0323 & 0.0323 & 0.0501 & 0.0371 & 0.0372 \\
\hline $\begin{array}{c}\text { C- } \\
\text { HA10 }\end{array}$ & 0.0322 & 0.0193 & 0.0259 & 0.0162 & 0.0113 & 0.0209 & 0.0161 & 0.0178 & 0.0178 & 0 & 0.0533 & 0.0194 & 0.0178 & 0.0226 & 0.0355 & 0.0340 \\
\hline $\begin{array}{c}\text { C- } \\
\text { HA11 }\end{array}$ & 0.0193 & 0.0323 & 0.0355 & 0.0097 & 0.0259 & 0.0290 & 0.0355 & 0.0290 & 0.0533 & 0.0178 & 0 & 0.0517 & 0.0501 & 0.0210 & 0.0517 & 0.0355 \\
\hline $\begin{array}{c}\text { C- } \\
\text { HA12 }\end{array}$ & 0.0291 & 0.0307 & 0.0355 & 0.0259 & 0.0323 & 0.0419 & 0.0484 & 0.0484 & 0.0533 & 0.0178 & 0.0533 & 0 & 0.0533 & 0.0226 & 0.0178 & 0.0404 \\
\hline $\begin{array}{c}\text { C- } \\
\text { HA13 }\end{array}$ & 0.0323 & 0.0371 & 0.0404 & 0.0226 & 0.0355 & 0.0209 & 0.0322 & 0.0323 & 0.0355 & 0.0178 & 0.0355 & 0.0355 & 0 & 0.0194 & 0.0194 & 0.0356 \\
\hline $\begin{array}{c}\text { C- } \\
\text { HA14 }\end{array}$ & 0.0436 & 0.0485 & 0.0420 & 0.0161 & 0.0388 & 0.0210 & 0.0355 & 0.0469 & 0.0355 & 0.0178 & 0.0355 & 0.0178 & 0.0355 & 0 & 0.0517 & 0.0355 \\
\hline $\begin{array}{c}\text { C- } \\
\text { HA15 }\end{array}$ & 0.0420 & 0.0452 & 0.0452 & 0.0161 & 0.0259 & 0.0242 & 0.0355 & 0.0533 & 0.0355 & 0.0178 & 0.0242 & 0.0178 & 0.0355 & 0.0178 & 0 & 0.0501 \\
\hline $\begin{array}{c}\text { C- } \\
\text { HA16 }\end{array}$ & 0.0420 & 0.0307 & 0.0501 & 0.0420 & 0.0194 & 0.0128 & 0.0404 & 0.0371 & 0.0517 & 0.0371 & 0.0436 & 0.0210 & 0.0355 & 0.0211 & 0.0178 & 0 \\
\hline \multicolumn{17}{|c|}{$(m)$} \\
\hline $\begin{array}{c}\text { C- } \\
\text { HA1 }\end{array}$ & 0 & 0.0340 & 0.0307 & 0.0501 & 0.0534 & 0.0387 & 0.0387 & 0.0517 & 0.0565 & 0.0420 & 0.0532 & 0.0533 & 0.0516 & 0.0565 & 0.0533 & 0.0436 \\
\hline $\begin{array}{c}\mathrm{C}- \\
\mathrm{HA} 2\end{array}$ & 0.0387 & 0 & 0.0355 & 0.0679 & 0.0242 & 0.0339 & 0.0371 & 0.0565 & 0.0420 & 0.0372 & 0.0436 & 0.0323 & 0.0388 & 0.0372 & 0.0404 & 0.0517 \\
\hline $\begin{array}{c}\mathrm{C}- \\
\mathrm{HA} 3\end{array}$ & 0.0387 & 0.0372 & 0 & 0.0533 & 0.0501 & 0.0274 & 0.0178 & 0.0566 & 0.0469 & 0.0420 & 0.0501 & 0.0419 & 0.0436 & 0.0453 & 0.0242 & 0.0339 \\
\hline $\begin{array}{c}\text { C- } \\
\text { HA4 }\end{array}$ & 0.0486 & 0.0372 & 0.0178 & 0 & 0.0711 & 0.0355 & 0.0388 & 0.0501 & 0.0404 & 0.0372 & 0.0420 & 0.0356 & 0.0340 & 0.0355 & 0.0404 & 0.0533 \\
\hline $\begin{array}{c}\text { C- } \\
\text { HA5 }\end{array}$ & 0.0548 & 0.0210 & 0.0501 & 0.0178 & 0 & 0.0533 & 0.0355 & 0.0501 & 0.0324 & 0.0501 & 0.0565 & 0.0468 & 0.0452 & 0.0468 & 0.0371 & 0.0533 \\
\hline $\begin{array}{c}\text { C- } \\
\text { HA6 }\end{array}$ & 0.0484 & 0.0420 & 0.0210 & 0.0420 & 0.0533 & 0 & 0.0355 & 0.0533 & 0.0355 & 0.0533 & 0.0485 & 0.0501 & 0.0533 & 0.0389 & 0.0517 & 0.0420 \\
\hline $\begin{array}{c}\text { C- } \\
\text { HA7 }\end{array}$ & 0.0500 & 0.0372 & 0.0420 & 0.0387 & 0.0355 & 0.0339 & 0 & 0.0469 & 0.0355 & 0.0533 & 0.0679 & 0.0501 & 0.0647 & 0.0533 & 0.0549 & 0.0614 \\
\hline $\begin{array}{c}\text { C- } \\
\text { HA8 }\end{array}$ & 0.0435 & 0.0404 & 0.0452 & 0.0340 & 0.0355 & 0.0355 & 0.0533 & 0 & 0.0242 & 0.0242 & 0.0290 & 0.0469 & 0.0647 & 0.0517 & 0.0549 & 0.0550 \\
\hline $\begin{array}{c}\text { C- } \\
\text { HA9 }\end{array}$ & 0.0452 & 0.0355 & 0.0484 & 0.0354 & 0.0372 & 0.0403 & 0.0533 & 0.0533 & 0 & 0.0372 & 0.0517 & 0.0501 & 0.0501 & 0.0679 & 0.0549 & 0.0549 \\
\hline $\begin{array}{c}\text { C- } \\
\text { HA10 }\end{array}$ & 0.0500 & 0.0371 & 0.0436 & 0.0340 & 0.0291 & 0.0386 & 0.0339 & 0.0355 & 0.0355 & 0 & 0.0711 & 0.0372 & 0.0355 & 0.0404 & 0.0533 & 0.0517 \\
\hline $\begin{array}{c}\text { C- } \\
\text { HA11 }\end{array}$ & 0.0371 & 0.0500 & 0.0533 & 0.0275 & 0.0437 & 0.0468 & 0.0533 & 0.0468 & 0.0711 & 0.0355 & 0 & 0.0695 & 0.0679 & 0.0388 & 0.0695 & 0.0533 \\
\hline
\end{tabular}


Table 6. Cont.

\begin{tabular}{|c|c|c|c|c|c|c|c|c|c|c|c|c|c|c|c|c|}
\hline \multicolumn{17}{|c|}{$(m)$} \\
\hline $\begin{array}{c}\text { C- } \\
\text { HA12 }\end{array}$ & 0.0468 & 0.0484 & 0.0533 & 0.0436 & 0.0501 & 0.0597 & 0.0661 & 0.0661 & 0.0711 & 0.0355 & 0.0711 & 0 & 0.0711 & 0.0404 & 0.0355 & 0.0582 \\
\hline $\begin{array}{c}\text { C- } \\
\text { HA13 } \\
\end{array}$ & 0.0501 & 0.0549 & 0.0581 & 0.0404 & 0.0533 & 0.0387 & 0.0500 & 0.0501 & 0.0533 & 0.0355 & 0.0533 & 0.0533 & 0 & 0.0372 & 0.0371 & 0.0533 \\
\hline $\begin{array}{c}\text { C- } \\
\text { HA14 } \\
\end{array}$ & 0.0614 & 0.0663 & 0.0598 & 0.0339 & 0.0566 & 0.0388 & 0.0533 & 0.0647 & 0.0533 & 0.0355 & 0.0533 & 0.0355 & 0.0533 & 0 & 0.0695 & 0.0533 \\
\hline $\begin{array}{c}\text { C- } \\
\text { HA15 } \\
\end{array}$ & 0.0597 & 0.0630 & 0.0630 & 0.0339 & 0.0437 & 0.0420 & 0.0533 & 0.0711 & 0.0533 & 0.0355 & 0.0420 & 0.0355 & 0.0533 & 0.0355 & 0 & 0.0678 \\
\hline $\begin{array}{c}\text { C- } \\
\text { HA16 }\end{array}$ & 0.0598 & 0.0484 & 0.0679 & 0.0598 & 0.0371 & 0.0306 & 0.0581 & 0.0549 & 0.0695 & 0.0549 & 0.0614 & 0.0387 & 0.0533 & 0.0389 & 0.0355 & 0 \\
\hline \multicolumn{17}{|c|}{ (u) } \\
\hline $\begin{array}{c}\text { C- } \\
\text { HA1 } \\
\end{array}$ & 0 & 0.0485 & 0.0484 & 0.0679 & 0.0630 & 0.0549 & 0.0565 & 0.0678 & 0.0678 & 0.0598 & 0.0646 & 0.0646 & 0.0613 & 0.0630 & 0.0646 & 0.0598 \\
\hline $\begin{array}{c}\text { C- } \\
\text { HA2 }\end{array}$ & 0.0533 & 0 & 0.0533 & 0.0711 & 0.0388 & 0.0517 & 0.0533 & 0.0711 & 0.0565 & 0.0549 & 0.0582 & 0.0484 & 0.0566 & 0.0549 & 0.0582 & 0.0614 \\
\hline $\begin{array}{c}\text { C- } \\
\text { HA3 }\end{array}$ & 0.0533 & 0.0550 & 0 & 0.0711 & 0.0678 & 0.0420 & 0.0355 & 0.0679 & 0.0598 & 0.0566 & 0.0614 & 0.0549 & 0.0582 & 0.0550 & 0.0420 & 0.0517 \\
\hline $\begin{array}{c}\text { C- } \\
\text { HA4 }\end{array}$ & 0.0598 & 0.0550 & 0.0355 & 0 & 0.0711 & 0.0533 & 0.0565 & 0.0679 & 0.0566 & 0.0550 & 0.0565 & 0.0518 & 0.0518 & 0.0533 & 0.0581 & 0.0662 \\
\hline $\begin{array}{c}\text { C- } \\
\text { HA5 }\end{array}$ & 0.0629 & 0.0388 & 0.0679 & 0.0355 & 0 & 0.0711 & 0.0533 & 0.0647 & 0.0469 & 0.0679 & 0.0711 & 0.0598 & 0.0598 & 0.0581 & 0.0549 & 0.0662 \\
\hline $\begin{array}{c}\text { C- } \\
\text { HA6 }\end{array}$ & 0.0565 & 0.0582 & 0.0388 & 0.0565 & 0.0711 & 0 & 0.0533 & 0.0711 & 0.0533 & 0.0711 & 0.0663 & 0.0662 & 0.0695 & 0.0550 & 0.0695 & 0.0598 \\
\hline $\begin{array}{c}\text { C- } \\
\text { HA7 }\end{array}$ & 0.0629 & 0.0533 & 0.0565 & 0.0549 & 0.0533 & 0.0517 & 0 & 0.0647 & 0.0533 & 0.0711 & 0.0695 & 0.0678 & 0.0679 & 0.0695 & 0.0711 & 0.0711 \\
\hline $\begin{array}{c}\text { C- } \\
\text { HA8 }\end{array}$ & 0.0597 & 0.0566 & 0.0598 & 0.0485 & 0.0533 & 0.0533 & 0.0711 & 0 & 0.0420 & 0.0420 & 0.0468 & 0.0647 & 0.0679 & 0.0695 & 0.0711 & 0.0663 \\
\hline $\begin{array}{c}\text { C- } \\
\text { HA9 }\end{array}$ & 0.0613 & 0.0517 & 0.0598 & 0.0516 & 0.0550 & 0.0549 & 0.0711 & 0.0711 & 0 & 0.0549 & 0.0695 & 0.0679 & 0.0679 & 0.0711 & 0.0711 & 0.0630 \\
\hline $\begin{array}{c}\text { C- } \\
\text { HA10 }\end{array}$ & 0.0630 & 0.0533 & 0.0582 & 0.0485 & 0.0452 & 0.0516 & 0.0517 & 0.0533 & 0.0533 & 0 & 0.0711 & 0.0549 & 0.0533 & 0.0582 & 0.0711 & 0.0663 \\
\hline $\begin{array}{c}\text { C- } \\
\text { HA11 } \\
\end{array}$ & 0.0501 & 0.0630 & 0.0678 & 0.0453 & 0.0582 & 0.0613 & 0.0711 & 0.0646 & 0.0711 & 0.0533 & 0 & 0.0711 & 0.0711 & 0.0565 & 0.0711 & 0.0646 \\
\hline $\begin{array}{c}\text { C- } \\
\text { HA12 }\end{array}$ & 0.0614 & 0.0630 & 0.0678 & 0.0614 & 0.0678 & 0.0645 & 0.0678 & 0.0678 & 0.0711 & 0.0533 & 0.0711 & 0 & 0.0711 & 0.0582 & 0.0533 & 0.0647 \\
\hline $\begin{array}{c}\text { C- } \\
\text { HA13 }\end{array}$ & 0.0662 & 0.0694 & 0.0678 & 0.0582 & 0.0678 & 0.0565 & 0.0678 & 0.0679 & 0.0711 & 0.0533 & 0.0711 & 0.0711 & 0 & 0.0549 & 0.0549 & 0.0647 \\
\hline $\begin{array}{c}\text { C- } \\
\text { HA14 }\end{array}$ & 0.0711 & 0.0711 & 0.0711 & 0.0517 & 0.0711 & 0.0565 & 0.0711 & 0.0679 & 0.0711 & 0.0533 & 0.0711 & 0.0533 & 0.0711 & 0 & 0.0711 & 0.0678 \\
\hline $\begin{array}{c}\text { C- } \\
\text { HA15 }\end{array}$ & 0.0694 & 0.0694 & 0.0711 & 0.0517 & 0.0582 & 0.0581 & 0.0711 & 0.0711 & 0.0711 & 0.0533 & 0.0565 & 0.0533 & 0.0711 & 0.0533 & 0 & 0.0695 \\
\hline $\begin{array}{c}\text { C- } \\
\text { HA16 }\end{array}$ & 0.0711 & 0.0662 & 0.0711 & 0.0711 & 0.0549 & 0.0452 & 0.0711 & 0.0711 & 0.0711 & 0.0711 & 0.0678 & 0.0549 & 0.0711 & 0.0550 & 0.0533 & 0 \\
\hline
\end{tabular}

Further, the total relation matrix is obtained by using the formula described in Equation (5) and shown in Table 7.

Table 7. Total relation matrix.

\begin{tabular}{|c|c|c|c|c|c|c|c|c|c|c|c|c|c|c|c|c|}
\hline \multicolumn{17}{|c|}{$(l)$} \\
\hline Factors & $\begin{array}{c}\text { C- } \\
\text { HA1 }\end{array}$ & $\begin{array}{c}\mathrm{C}- \\
\mathrm{HA} 2\end{array}$ & $\begin{array}{c}\mathrm{C}- \\
\mathrm{HA} 3\end{array}$ & $\begin{array}{c}\text { C- } \\
\text { HA4 }\end{array}$ & $\begin{array}{c}\mathrm{C}- \\
\mathrm{HA} 5\end{array}$ & $\begin{array}{c}\text { C- } \\
\text { HA6 }\end{array}$ & $\begin{array}{c}\text { C- } \\
\text { HA7 }\end{array}$ & $\begin{array}{c}\text { C- } \\
\text { HA8 }\end{array}$ & $\begin{array}{c}\text { C- } \\
\text { HA9 }\end{array}$ & $\begin{array}{c}\text { C-HA } \\
10\end{array}$ & $\begin{array}{c}\text { C- } \\
\text { HA11 }\end{array}$ & $\begin{array}{c}\mathrm{C}- \\
\mathrm{HA12}\end{array}$ & $\begin{array}{c}\mathrm{C}- \\
\text { HA13 }\end{array}$ & $\begin{array}{c}\text { C- } \\
\text { HA14 }\end{array}$ & $\begin{array}{c}\text { C- } \\
\text { HA15 }\end{array}$ & $\begin{array}{c}\text { C- } \\
\text { HA16 }\end{array}$ \\
\hline $\begin{array}{c}\mathrm{C}- \\
\mathrm{HA} 1\end{array}$ & 0.0240 & 0.0363 & 0.0356 & 0.0481 & 0.0558 & 0.0378 & 0.0428 & 0.0605 & 0.0612 & 0.0407 & 0.0608 & 0.0557 & 0.0595 & 0.0580 & 0.0576 & 0.0521 \\
\hline $\begin{array}{c}\mathrm{C}- \\
\mathrm{HA} 2\end{array}$ & 0.0396 & 0.0160 & 0.0349 & 0.0628 & 0.0334 & 0.0291 & 0.0364 & 0.0594 & 0.0423 & 0.0328 & 0.0459 & 0.0313 & 0.0416 & 0.0354 & 0.0405 & 0.0544 \\
\hline $\begin{array}{c}\mathrm{C}- \\
\mathrm{HA} 3\end{array}$ & 0.0385 & 0.0340 & 0.0169 & 0.0475 & 0.0480 & 0.0229 & 0.0171 & 0.0583 & 0.0461 & 0.0364 & 0.0512 & 0.0400 & 0.0453 & 0.0426 & 0.0244 & 0.0361 \\
\hline $\begin{array}{c}\mathrm{C}- \\
\mathrm{HA} 4\end{array}$ & 0.0491 & 0.0342 & 0.0184 & 0.0133 & 0.0678 & 0.0313 & 0.0379 & 0.0529 & 0.0404 & 0.0332 & 0.0448 & 0.0345 & 0.0371 & 0.0340 & 0.0403 & 0.0557 \\
\hline
\end{tabular}


Table 7. Cont.

\begin{tabular}{|c|c|c|c|c|c|c|c|c|c|c|c|c|c|c|c|c|}
\hline \multicolumn{17}{|c|}{ (l) } \\
\hline $\begin{array}{c}\text { C- } \\
\text { HA5 }\end{array}$ & 0.0566 & 0.0213 & 0.0514 & 0.0157 & 0.0183 & 0.0493 & 0.0363 & 0.0552 & 0.0357 & 0.0468 & 0.0611 & 0.0475 & 0.0506 & 0.0461 & 0.0393 & 0.0570 \\
\hline $\begin{array}{c}\text { C- } \\
\text { HA6 }\end{array}$ & 0.0514 & 0.0419 & 0.0240 & 0.0391 & 0.0535 & 0.0158 & 0.0375 & 0.0592 & 0.0388 & 0.0500 & 0.0540 & 0.0508 & 0.0585 & 0.0389 & 0.0538 & 0.0481 \\
\hline $\begin{array}{c}\text { C- } \\
\text { HA7 }\end{array}$ & 0.0561 & 0.0408 & 0.0479 & 0.0389 & 0.0395 & 0.0335 & 0.0231 & 0.0569 & 0.0433 & 0.0524 & 0.0762 & 0.0538 & 0.0731 & 0.0553 & 0.0600 & 0.0698 \\
\hline $\begin{array}{c}\text { C- } \\
\text { HA8 }\end{array}$ & 0.0457 & 0.0399 & 0.0464 & 0.0316 & 0.0357 & 0.0315 & 0.0530 & 0.0239 & 0.0272 & 0.0216 & 0.0340 & 0.0460 & 0.0679 & 0.0498 & 0.0546 & 0.0586 \\
\hline $\begin{array}{c}\text { C- } \\
\text { HA9 }\end{array}$ & 0.0512 & 0.0388 & 0.0534 & 0.0354 & 0.0407 & 0.0391 & 0.0570 & 0.0629 & 0.0246 & 0.0367 & 0.0601 & 0.0531 & 0.0591 & 0.0692 & 0.0597 & 0.0631 \\
\hline $\begin{array}{c}\text { C- } \\
\text { HA10 }\end{array}$ & 0.0506 & 0.0360 & 0.0439 & 0.0306 & 0.0286 & 0.0342 & 0.0338 & 0.0402 & 0.0381 & 0.0142 & 0.0730 & 0.0370 & 0.0397 & 0.0386 & 0.0537 & 0.0545 \\
\hline $\begin{array}{c}\text { C- } \\
\text { HA11 }\end{array}$ & 0.0457 & 0.0543 & 0.0606 & 0.0300 & 0.0486 & 0.0474 & 0.0594 & 0.0599 & 0.0784 & 0.0370 & 0.0302 & 0.0738 & 0.0786 & 0.0439 & 0.0747 & 0.0646 \\
\hline $\begin{array}{c}\mathrm{C}- \\
\text { HA12 }\end{array}$ & 0.0569 & 0.0540 & 0.0617 & 0.0469 & 0.0571 & 0.0610 & 0.0732 & 0.0798 & 0.0801 & 0.0391 & 0.0837 & 0.0273 & 0.0844 & 0.0479 & 0.0459 & 0.0714 \\
\hline $\begin{array}{c}\text { C- } \\
\text { HA13 }\end{array}$ & 0.0549 & 0.0556 & 0.0615 & 0.0405 & 0.0556 & 0.0376 & 0.0529 & 0.0592 & 0.0584 & 0.0353 & 0.0614 & 0.0562 & 0.0271 & 0.0401 & 0.0417 & 0.0610 \\
\hline $\begin{array}{c}\text { C- } \\
\text { HA14 }\end{array}$ & 0.0695 & 0.0699 & 0.0668 & 0.0369 & 0.0615 & 0.0397 & 0.0591 & 0.0773 & 0.0615 & 0.0376 & 0.0645 & 0.0423 & 0.0652 & 0.0241 & 0.0760 & 0.0652 \\
\hline $\begin{array}{c}\text { C- } \\
\text { HA15 }\end{array}$ & 0.0658 & 0.0648 & 0.0677 & 0.0363 & 0.0475 & 0.0410 & 0.0573 & 0.0808 & 0.0595 & 0.0364 & 0.0519 & 0.0405 & 0.0630 & 0.0402 & 0.0240 & 0.0763 \\
\hline $\begin{array}{c}\text { C- } \\
\text { HA16 }\end{array}$ & 0.0663 & 0.0514 & 0.0724 & 0.0605 & 0.0425 & 0.0310 & 0.0623 & 0.0659 & 0.0758 & 0.0551 & 0.0716 & 0.0447 & 0.0635 & 0.0442 & 0.0431 & 0.0292 \\
\hline \multicolumn{17}{|c|}{$(m)$} \\
\hline $\begin{array}{c}\text { C- } \\
\text { HA1 }\end{array}$ & 0.1108 & 0.1327 & 0.1362 & 0.1400 & 0.1529 & 0.1281 & 0.1418 & 0.1709 & 0.1636 & 0.1322 & 0.1696 & 0.1540 & 0.1678 & 0.1548 & 0.1590 & 0.1608 \\
\hline $\begin{array}{c}\mathrm{C}- \\
\mathrm{HA} 2\end{array}$ & 0.1334 & 0.0866 & 0.1258 & 0.1455 & 0.1128 & 0.1109 & 0.1262 & 0.1591 & 0.1356 & 0.1158 & 0.1447 & 0.1209 & 0.1400 & 0.1236 & 0.1327 & 0.1525 \\
\hline $\begin{array}{c}\mathrm{C}- \\
\mathrm{HA} 3\end{array}$ & 0.1319 & 0.1209 & 0.0906 & 0.1302 & 0.1355 & 0.1047 & 0.1070 & 0.1577 & 0.1388 & 0.1189 & 0.1495 & 0.1290 & 0.1432 & 0.1302 & 0.1166 & 0.1345 \\
\hline $\begin{array}{c}\mathrm{C}- \\
\mathrm{HA} 4\end{array}$ & 0.1433 & 0.1221 & 0.1106 & 0.0807 & 0.1558 & 0.1137 & 0.1282 & 0.1536 & 0.1344 & 0.1168 & 0.1444 & 0.1247 & 0.1365 & 0.1228 & 0.1332 & 0.1546 \\
\hline $\begin{array}{c}\text { C- } \\
\text { HA5 }\end{array}$ & 0.1541 & 0.1130 & 0.1460 & 0.1037 & 0.0940 & 0.1344 & 0.1302 & 0.1597 & 0.1334 & 0.1332 & 0.1641 & 0.1408 & 0.1533 & 0.1380 & 0.1358 & 0.1597 \\
\hline $\begin{array}{c}\text { C- } \\
\text { HA6 }\end{array}$ & 0.1507 & 0.1343 & 0.1210 & 0.1277 & 0.1467 & 0.0859 & 0.1328 & 0.1652 & 0.1380 & 0.1377 & 0.1588 & 0.1453 & 0.1626 & 0.1325 & 0.1513 & 0.1527 \\
\hline $\begin{array}{c}\text { C- } \\
\text { HA7 }\end{array}$ & 0.1612 & 0.1389 & 0.1500 & 0.1328 & 0.1389 & 0.1257 & 0.1071 & 0.1695 & 0.1483 & 0.1453 & 0.1866 & 0.1541 & 0.1830 & 0.1540 & 0.1632 & 0.1800 \\
\hline $\begin{array}{c}\text { C- } \\
\text { HA8 }\end{array}$ & 0.1425 & 0.1299 & 0.1400 & 0.1179 & 0.1270 & 0.1161 & 0.1451 & 0.1108 & 0.1240 & 0.1077 & 0.1366 & 0.1381 & 0.1687 & 0.1405 & 0.1493 & 0.1599 \\
\hline $\begin{array}{c}\text { C- } \\
\text { HA9 }\end{array}$ & 0.1556 & 0.1361 & 0.1544 & 0.1285 & 0.1392 & 0.1303 & 0.1564 & 0.1743 & 0.1118 & 0.1293 & 0.1700 & 0.1524 & 0.1684 & 0.1665 & 0.1619 & 0.1725 \\
\hline $\begin{array}{c}\text { C- } \\
\text { HA10 }\end{array}$ & 0.1460 & 0.1250 & 0.1365 & 0.1159 & 0.1190 & 0.1177 & 0.1254 & 0.1427 & 0.1333 & 0.0822 & 0.1730 & 0.1283 & 0.1402 & 0.1285 & 0.1473 & 0.1548 \\
\hline $\begin{array}{c}\text { C- } \\
\text { HA11 }\end{array}$ & 0.1551 & 0.1555 & 0.1659 & 0.1276 & 0.1512 & 0.1425 & 0.1633 & 0.1764 & 0.1860 & 0.1338 & 0.1287 & 0.1770 & 0.1923 & 0.1465 & 0.1811 & 0.1789 \\
\hline $\begin{array}{c}\mathrm{C}- \\
\text { HA12 } \\
\end{array}$ & 0.1707 & 0.1597 & 0.1716 & 0.1482 & 0.1639 & 0.1598 & 0.1813 & 0.2008 & 0.1924 & 0.1400 & 0.2029 & 0.1191 & 0.2030 & 0.1549 & 0.1580 & 0.1906 \\
\hline $\begin{array}{c}\mathrm{C}- \\
\text { HA13 }\end{array}$ & 0.1589 & 0.1520 & 0.1619 & 0.1332 & 0.1532 & 0.1285 & 0.1522 & 0.1704 & 0.1617 & 0.1276 & 0.1710 & 0.1552 & 0.1197 & 0.1382 & 0.1443 & 0.1702 \\
\hline $\begin{array}{c}\mathrm{C}- \\
\text { HA14 }\end{array}$ & 0.1797 & 0.1722 & 0.1736 & 0.1358 & 0.1652 & 0.1366 & 0.1647 & 0.1952 & 0.1714 & 0.1359 & 0.1811 & 0.1482 & 0.1812 & 0.1116 & 0.1841 & 0.1814 \\
\hline $\begin{array}{c}\text { C- } \\
\text { HA15 }\end{array}$ & 0.1725 & 0.1638 & 0.1709 & 0.1319 & 0.1481 & 0.1345 & 0.1594 & 0.1945 & 0.1657 & 0.1315 & 0.1650 & 0.1430 & 0.1752 & 0.1411 & 0.1128 & 0.1882 \\
\hline $\begin{array}{c}\text { C- } \\
\text { HA16 }\end{array}$ & 0.1745 & 0.1523 & 0.1769 & 0.1567 & 0.1450 & 0.1262 & 0.1657 & 0.1818 & 0.1830 & 0.1509 & 0.1857 & 0.1485 & 0.1773 & 0.1465 & 0.1501 & 0.1269 \\
\hline \multicolumn{17}{|c|}{ (u) } \\
\hline $\begin{array}{c}\text { C- } \\
\text { HA1 }\end{array}$ & 0.6146 & 0.6302 & 0.6464 & 0.6282 & 0.6568 & 0.6060 & 0.6709 & 0.7324 & 0.6748 & 0.6366 & 0.7055 & 0.6654 & 0.7030 & 0.6513 & 0.6834 & 0.6966 \\
\hline
\end{tabular}


Table 7. Cont.

\begin{tabular}{|c|c|c|c|c|c|c|c|c|c|c|c|c|c|c|c|c|}
\hline \multicolumn{17}{|c|}{ (u) } \\
\hline $\begin{array}{c}\mathrm{C}- \\
\mathrm{HA} 2\end{array}$ & 0.6183 & 0.5397 & 0.6046 & 0.5888 & 0.5895 & 0.5604 & 0.6209 & 0.6845 & 0.6181 & 0.5880 & 0.6503 & 0.6048 & 0.6495 & 0.5990 & 0.6303 & 0.6493 \\
\hline $\begin{array}{c}\text { C- } \\
\text { HA3 }\end{array}$ & 0.6107 & 0.5842 & 0.5470 & 0.5814 & 0.6084 & 0.5456 & 0.5972 & 0.6734 & 0.6134 & 0.5824 & 0.6457 & 0.6032 & 0.6429 & 0.5918 & 0.6080 & 0.6327 \\
\hline $\begin{array}{c}\text { C- } \\
\text { HA4 }\end{array}$ & 0.6297 & 0.5964 & 0.5944 & 0.5265 & 0.6233 & 0.5674 & 0.6293 & 0.6874 & 0.6233 & 0.5937 & 0.6549 & 0.6132 & 0.6511 & 0.6028 & 0.6358 & 0.6593 \\
\hline $\begin{array}{c}\text { C- } \\
\text { HA5 }\end{array}$ & 0.6520 & 0.6011 & 0.6429 & 0.5798 & 0.5766 & 0.6008 & 0.6458 & 0.7059 & 0.6348 & 0.6240 & 0.6889 & 0.6402 & 0.6792 & 0.6260 & 0.6528 & 0.6796 \\
\hline $\begin{array}{c}\text { C- } \\
\text { HA6 }\end{array}$ & 0.6699 & 0.6406 & 0.6397 & 0.6195 & 0.6653 & 0.5558 & 0.6698 & 0.7371 & 0.6635 & 0.6485 & 0.7089 & 0.6687 & 0.7121 & 0.6457 & 0.6896 & 0.6986 \\
\hline $\begin{array}{c}\text { C- } \\
\text { HA7 }\end{array}$ & 0.6911 & 0.6513 & 0.6708 & 0.6329 & 0.6646 & 0.6184 & 0.6346 & 0.7482 & 0.6794 & 0.6630 & 0.7280 & 0.6850 & 0.7270 & 0.6734 & 0.7065 & 0.7245 \\
\hline $\begin{array}{c}\text { C- } \\
\text { HA8 }\end{array}$ & 0.6468 & 0.6147 & 0.6330 & 0.5893 & 0.6245 & 0.5823 & 0.6591 & 0.6425 & 0.6279 & 0.5980 & 0.6641 & 0.6412 & 0.6834 & 0.6334 & 0.6639 & 0.6769 \\
\hline $\begin{array}{c}\text { C- } \\
\text { HA9 }\end{array}$ & 0.6922 & 0.6523 & 0.6763 & 0.6322 & 0.6688 & 0.6237 & 0.7038 & 0.7569 & 0.6312 & 0.6511 & 0.7307 & 0.6879 & 0.7299 & 0.6776 & 0.7092 & 0.7201 \\
\hline $\begin{array}{c}\text { C- } \\
\text { HA10 }\end{array}$ & 0.6360 & 0.5990 & 0.6184 & 0.5768 & 0.6039 & 0.5687 & 0.6284 & 0.6784 & 0.6248 & 0.5447 & 0.6716 & 0.6195 & 0.6564 & 0.6103 & 0.6508 & 0.6628 \\
\hline $\begin{array}{c}\text { C- } \\
\text { HA11 }\end{array}$ & 0.6801 & 0.6604 & 0.6815 & 0.6251 & 0.6696 & 0.6276 & 0.7016 & 0.7491 & 0.6956 & 0.6480 & 0.6637 & 0.6889 & 0.7307 & 0.6628 & 0.7069 & 0.7193 \\
\hline $\begin{array}{c}\text { C- } \\
\text { HA12 }\end{array}$ & 0.7038 & 0.6732 & 0.6945 & 0.6521 & 0.6919 & 0.6430 & 0.7123 & 0.7670 & 0.7091 & 0.6612 & 0.7447 & 0.6362 & 0.7450 & 0.6776 & 0.7053 & 0.7338 \\
\hline $\begin{array}{c}\text { C- } \\
\text { HA13 }\end{array}$ & 0.7068 & 0.6776 & 0.6934 & 0.6482 & 0.6904 & 0.6348 & 0.7110 & 0.7657 & 0.7079 & 0.6599 & 0.7433 & 0.7013 & 0.6772 & 0.6736 & 0.7054 & 0.7324 \\
\hline $\begin{array}{c}\text { C- } \\
\text { HA14 }\end{array}$ & 0.7293 & 0.6963 & 0.7141 & 0.6588 & 0.7106 & 0.6509 & 0.7320 & 0.7853 & 0.7259 & 0.6769 & 0.7621 & 0.7031 & 0.7626 & 0.6387 & 0.7380 & 0.7540 \\
\hline $\begin{array}{c}\text { C- } \\
\text { HA15 }\end{array}$ & 0.7007 & 0.6690 & 0.6872 & 0.6343 & 0.6728 & 0.6275 & 0.7047 & 0.7586 & 0.6987 & 0.6513 & 0.7206 & 0.6764 & 0.7340 & 0.6633 & 0.6440 & 0.7271 \\
\hline $\begin{array}{c}\text { C- } \\
\text { HA16 }\end{array}$ & 0.7120 & 0.6755 & 0.6967 & 0.6605 & 0.6795 & 0.6250 & 0.7146 & 0.7692 & 0.7086 & 0.6762 & 0.7411 & 0.6876 & 0.7440 & 0.6744 & 0.7049 & 0.6726 \\
\hline
\end{tabular}

The value for the causal diagram is obtained $(D+R)$ and $(D-R)$ and shown in Table 8 .

Table 8. Values for the causal diagram.

\begin{tabular}{|c|c|c|c|c|c|c|c|c|c|c|c|c|c|c|}
\hline & \multicolumn{3}{|c|}{ Di } & \multicolumn{3}{|c|}{$\mathbf{R i}$} & \multicolumn{3}{|c|}{$\mathrm{Di}+\mathbf{R i}$} & \multicolumn{3}{|c|}{$\mathbf{D i}-\mathbf{R i}$} & \multirow[t]{2}{*}{ Crisp Di + Ri } & \multirow[t]{2}{*}{ Crisp Di - Ri } \\
\hline & 1 & m & $\mathbf{u}$ & 1 & m & $\mathbf{u}$ & 1 & m & $\mathbf{u}$ & 1 & $\mathbf{m}$ & $\mathbf{u}$ & & \\
\hline C-HA1 & 0.7865 & 2.3754 & 10.6020 & 0.8219 & 2.4409 & 10.6942 & 1.6084 & 4.8163 & 21.2962 & -9.9077 & -0.0655 & 9.7801 & 7.4845 & -0.0734 \\
\hline C-HA2 & 0.6357 & 2.0659 & 9.7961 & 0.6891 & 2.1950 & 10.1616 & 1.3248 & 4.2609 & 19.9577 & -9.5259 & -0.1291 & 9.1070 & 6.8647 & -0.1523 \\
\hline C-HA3 & 0.6053 & 2.0391 & 9.6681 & 0.7634 & 2.3318 & 10.4412 & 1.3686 & 4.3709 & 20.1093 & -9.8359 & -0.2927 & 8.9047 & 6.9706 & -0.3208 \\
\hline C-HA4 & 0.6249 & 2.0755 & 9.8886 & 0.6143 & 2.0564 & 9.8343 & 1.2393 & 4.1319 & 19.7229 & -9.2094 & 0.0191 & 9.2742 & 6.7284 & 0.0038 \\
\hline C-HA5 & 0.6883 & 2.1934 & 10.2305 & 0.7340 & 2.2485 & 10.3966 & 1.4223 & 4.4419 & 20.6271 & -9.7083 & -0.0551 & 9.4965 & 7.1040 & -0.0798 \\
\hline C-HA6 & 0.7154 & 2.2433 & 10.6334 & 0.5821 & 1.9955 & 9.6379 & 1.2975 & 4.2388 & 20.2714 & -8.9226 & 0.2477 & 10.0513 & 6.8942 & 0.2898 \\
\hline C-HA7 & 0.8205 & 2.4385 & 10.8986 & 0.7390 & 2.2872 & 10.7361 & 1.5596 & 4.7257 & 21.6347 & -9.9155 & 0.1513 & 10.1596 & 7.4653 & 0.1013 \\
\hline C-HA8 & 0.6675 & 2.1542 & 10.1811 & 0.9520 & 2.6826 & 11.6417 & 1.6194 & 4.8368 & 21.8227 & -10.9742 & -0.5285 & 9.2291 & 7.5758 & -0.5656 \\
\hline C-HA9 & 0.8040 & 2.4078 & 10.9438 & 0.8113 & 2.4215 & 10.6369 & 1.6153 & 4.8293 & 21.5807 & -9.8329 & -0.0137 & 10.1325 & 7.5354 & 0.0175 \\
\hline $\begin{array}{c}\text { C- } \\
\text { HA10 }\end{array}$ & 0.6468 & 2.1158 & 9.9505 & 0.6052 & 2.0387 & 10.1036 & 1.2520 & 4.1546 & 20.0542 & -9.4569 & 0.0771 & 9.3453 & 6.7966 & 0.0093 \\
\hline $\begin{array}{c}\text { C- } \\
\text { HA11 }\end{array}$ & 0.8871 & 2.5618 & 10.9109 & 0.9245 & 2.6316 & 11.2241 & 1.8116 & 5.1934 & 22.1350 & -10.3370 & -0.0698 & 9.9864 & 7.8864 & -0.1082 \\
\hline $\begin{array}{c}\mathrm{C}- \\
\mathrm{HA12}\end{array}$ & 0.9704 & 2.7169 & 11.1506 & 0.7345 & 2.2785 & 10.5225 & 1.7049 & 4.9954 & 21.6731 & -9.5521 & 0.4384 & 10.4161 & 7.6732 & 0.3519 \\
\hline $\begin{array}{c}\mathrm{C}- \\
\text { HA13 } \\
\end{array}$ & 0.7989 & 2.3982 & 11.1290 & 0.9143 & 2.6124 & 11.2279 & 1.7132 & 5.0107 & 22.3570 & -10.4290 & -0.2142 & 10.2147 & 7.7816 & -0.1691 \\
\hline $\begin{array}{c}\text { C- } \\
\text { HA14 }\end{array}$ & 0.9173 & 2.6178 & 11.4387 & 0.7084 & 2.2302 & 10.3018 & 1.6257 & 4.8480 & 21.7405 & -9.3845 & 0.3876 & 10.7303 & 7.5725 & 0.3926 \\
\hline
\end{tabular}


Table 8. Cont.

\begin{tabular}{|c|c|c|c|c|c|c|c|c|c|c|c|c|c|c|}
\hline & \multicolumn{3}{|c|}{ Di } & \multicolumn{3}{|c|}{$\mathbf{R i}$} & \multicolumn{3}{|c|}{$\mathrm{Di}+\mathbf{R i}$} & \multicolumn{3}{|c|}{$\mathbf{D i}-\mathbf{R} \mathbf{i}$} & \multirow[t]{2}{*}{ Crisp Di + Ri } & \multirow[t]{2}{*}{ Crisp Di $-\mathrm{Ri}$} \\
\hline & 1 & $\mathbf{m}$ & $\mathbf{u}$ & 1 & m & $\mathbf{u}$ & 1 & m & $\mathbf{u}$ & 1 & m & $\mathbf{u}$ & & \\
\hline $\begin{array}{c}\text { C- } \\
\text { HA15 }\end{array}$ & 0.8528 & 2.4981 & 10.9703 & 0.7892 & 2.3806 & 10.8348 & 1.6420 & 4.8788 & 21.8050 & -9.9820 & 0.1175 & 10.1810 & 7.6048 & 0.0757 \\
\hline $\begin{array}{c}\text { C- } \\
\text { HA16 }\end{array}$ & 0.8794 & 2.5481 & 11.1423 & 0.9174 & 2.6183 & 11.1395 & 1.7968 & 5.1664 & 22.2818 & -10.2601 & -0.0702 & 10.2249 & 7.8870 & -0.0632 \\
\hline
\end{tabular}

Based on the $(D-R)$ values, the cause-and-effect relationship is established among the factors. The impact results are shown in Table 9.

Table 9. Impact results of factors.

\begin{tabular}{cccc}
\hline Factors & $\mathbf{D}+\mathbf{R}$ & $\mathbf{D}-\mathbf{R}$ & Impact \\
\hline C-HA1 & 7.4845 & -0.0734 & Effect \\
\hline C-HA2 & 6.8647 & -0.1523 & Effect \\
\hline C-HA3 & 6.9706 & -0.3208 & Effect \\
\hline C-HA4 & 6.7284 & 0.0038 & Cause \\
\hline C-HA5 & 7.1040 & -0.0798 & Effect \\
\hline C-HA6 & 6.8942 & 0.2898 & Cause \\
\hline C-HA7 & 7.4653 & 0.1013 & Cause \\
\hline C-HA8 & 7.5758 & -0.5656 & Effect \\
\hline C-HA9 & 7.5354 & 0.0175 & Cause \\
\hline C-HA10 & 6.7966 & 0.0093 & Cause \\
\hline C-HA11 & 7.8864 & -0.1082 & Effect \\
\hline C-HA12 & 7.6732 & 0.3519 & Cause \\
\hline C-HA13 & 7.7816 & -0.1691 & Effect \\
\hline C-HA14 & 7.5725 & 0.3926 & Cause \\
\hline C-HA15 & 7.6048 & 0.0757 & Cause \\
\hline C-HA16 & 7.8870 & -0.0632 & Effect \\
\hline
\end{tabular}

In order to obtain the digraph and to eliminate minor effects, the threshold value $(\alpha)$ is calculated using Equation (6).

$$
\alpha=\left(\sum(i=1) \hat{n} \sum_{-}(j=1) \hat{n}\left[t_{-} i j\right]\right) / N=1.9192
$$

A network relationship map (NRM) was established, based on the value of $\alpha$ (1.91). This presented the significance or strength of the relationship, which are shown in the digraph with an arrow (Figure 3). The values that were more than the threshold value of 1.51 are included in the total relation matrix; see Table 8. A network relationship map (NRM) was established. 


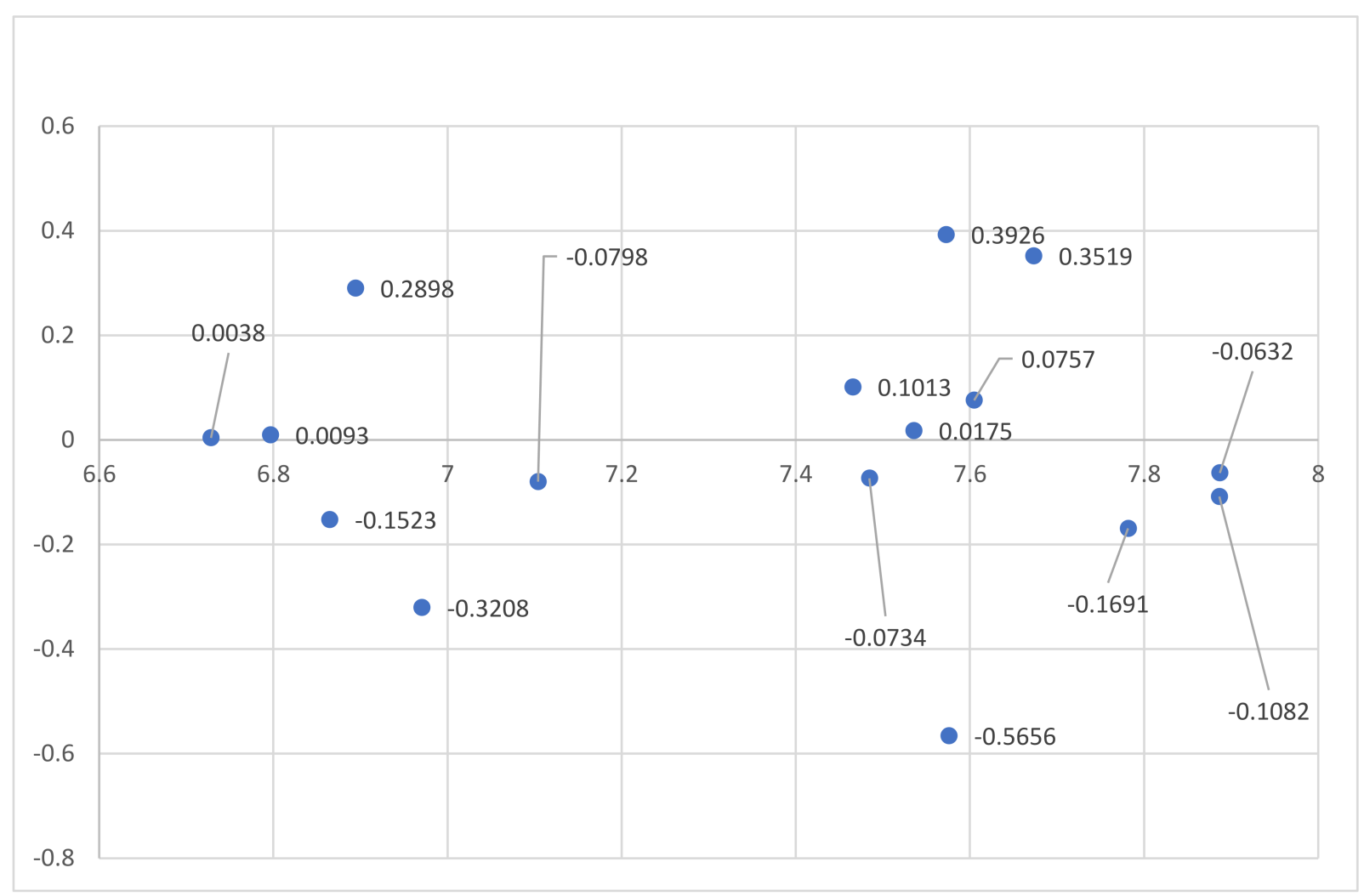

Figure 3. Cause-and-effect relationship.

\section{Discussion of Findings}

The study explored the key factors that needed to be focused on during pandemics to enhance the operational effectiveness of humanitarian activities (HAs). These critical factors are grouped as causal factors where $\mathrm{D}-\mathrm{R}$ values are positive, shown in Table 8 . The results imply that these causal factors drive the other factors in the system. On the basis of the values of $\mathrm{D}-\mathrm{R}$, the factors are categorized into two groups: cause and effect. The causal factors include risk communication and community engagement (C-HA4), agile and adaptive governance (C-HA6), information system (C-HA7), prevention and control (C-HA9), maintaining essential health services (C-HA10), preparedness and pandemic response practices (C-HA12), blockchain-enabled digital humanitarian network (BT-DHN) design (C-HA14), and human security (C-HA15). The causal group factors are elaborated in the following section.

From Table 9, it is visible that blockchain-enabled digital humanitarian network (BT-DHN) design is the most significant factor during the pandemic. Pandemics or disasters are highly complex and develop a challenging environment for humanitarian organizations $[19,20]$. Intervening during a disaster requires an in-depth understanding of the situation and the context. Social networking sites and social media are used by the people extensively in the front lines of disaster or directly affected to call for help; search for information; and share photos, videos, and text about their personal experiences and communication about safety to their families and friends. People use different digital channels for sharing real-time data to communicate about recent updates [21]. Digital innovation and technologies offer opportunities to save more lives and explore better ways to communicate to meet the needs of affected people during the crisis. Blockchain-enabled digital humanitarian network (BT-DHN) design develops participative management and provides real-time information flow to employ big data for the humanitarian response for effective relief operations. This new method of humanitarian aid is a cost-effective, attractive, and value-neutral way of addressing the needs of those experiencing fragility [11]. This factor regularly encompasses the uses of mobile phones, social media, crisis mapping, 
crowdsourcing, digital payment systems, and geospatial technologies. The technological innovations have brought the blockchain-enabled digital humanitarian network (BT-DHN) recently to provide support to the people who are the sufferers of a natural disaster or pandemic situation [92] and act as a liaison between the different digital HOs to work on a project. Table 9 shows that the preparedness and pandemic response practices factor (C-HA1) has received the second-highest weightage (0.3519), indicating the importance of this factor in the pandemic situation. Unlike regional events such as hurricanes, earthquakes, or terrorist attacks, a pandemic is a recurring worldwide occurrence with global implications. Pandemic outbreaks highlight the critical significance of effective planning and response to minimize the mortality rate, social and economic disruptions, and organizational risk. The preparedness and pandemic response practices must include the ability to react immediately and faster and be adaptive to the changing scenarios with the changing phases of the pandemic [87,88]. During a pandemic, global supply chains, as well as local supply chains, need to develop and implement planning and response to assess the organizational performance and consider improvements in the light of an event. This factor includes planning, testing, and regular reviews that can enhance the organizational effectiveness of HOs and may place them in a better position to reduce or mitigate the impact of global disruption. It will also provide vigilance, resiliency, and an effective roadmap to direct future activities, which may include an action plan for pandemic planning and response. The third most important factor is agile and adaptive governance (C-HA6), which is required during pandemic times. This is in line with the previous research study on agility in the humanitarian supply chains conducted by Dubey et al. [2], which empirically proved the significance of agility for HSC and HAs. Moreover, the impact of information systems has also been revealed in the study. The current study has a similar direction for managing HSCs that justifies the fourth important causing factor, i.e., information system. The information related to the causes of spread needs to be communicated at a wider level through the stakeholder's participation [90]. The community needs to be empowered with the recent updates, causes, precautions, vaccine (if available), helpline numbers, medical supplies, etc. The pause to the spread can be achieved through this factor. From the results, the factors of multi-modal transportation (C-HA1), leadership during pandemic crisis (C-HA2), empowering the stakeholders (C-HA3), information resource orchestration (C-HA5), capacity building of stakeholders (C-HA8), inter-organizational coordination and collaboration (C-HA11), surveillance for vulnerable groups (C-HA13), and societal response (C-HA16) are categorized as effect group factors.

The previous studies have suggested that effective HSCs are dependent on the people who lead the operations during the pandemic. The role of the leader who initiates and bind the HOs are the game-changer during an emergency situation. The transportation has to be with multiple modes as the essentials, and the healthcare supplies need to be supplied on time, and thus all humanitarian operations and their effectiveness are dependent on transportation and logistics and coordination among the stakeholders such as government, people, NGOs, private organizations, etc.

\section{Implications}

This paper provides insights for decision-makers, policymakers, and stakeholders to consider the critical factors for implementing strategic actions during COVID-19 pandemic disruption. The increasing engagement of the humanitarian organizations with stakeholders is an extremely positive indicator. The HOs need to work more strategically with other partners, as these may become larger stakeholders in international humanitarian response. The humanitarian system will be more structured, agile, and prepared than it was before. The paper has explored the factors to be considered for developing a 'new normal' environment, which is more prepared for dealing with the pandemic situation. The blockchain-enabled digital humanitarian network (BT-DHN) will act as a base for partnerships and enhance the effectiveness of HAs. The increasing number of technological advancements on the part of humanitarian organizations users offers an opportunity for 
extending the blockchain-enabled digital humanitarian network (BT-DHN) for detecting physical activity, speech and auditory context, location tracking, etc. The individuals can directly engage in pandemic response activities using a combination of cloud, crowd, and SMS technologies. With the Internet of Things (IoT) technology, the sensor data will match or even outgrow social data soon. This will have a strong impact on the humanitarian efforts. Moreover, satellite imagery can help the delivery of aid in the affected areas. The humanitarian sector needs to connect the data across preparedness, response, and recovery in a pandemic situation. The humanitarian organizations cannot achieve the objectives alone. Thus, collaboration with the private sector is a necessity. The pandemic has created a need for an alliance between the private and public sectors to transform the humanitarian supply chains.

\section{Conclusions and Limitations}

With the continuous spread of the coronavirus pandemic across the world, disruptions, and falling economies, the catastrophic impact on the crisis-affected population is highly visible. Stretched aid budgets in the humanitarian sector present enormous challenges. The lessons from the COVID-19 have made the organizations prepared for the 'new normal' situation. Mobile technology is aiming to reach seven million people to use life-enhancing mobile-enabled services during disaster preparedness, response, and recovery by 2021 . The delivery and impact of assistance by catalyzing partnerships and innovation for new digital humanitarian services advocating for enabling policy environment are to be accelerated. With the help of this paper, we have explored the critical factors to be considered for enhancing the operational effectiveness of humanitarian organizations during the pandemic. This research approach is certainly in line with the increasing trend towards pandemics and new normal situations. The results of this study show blockchain-enabled digital humanitarian network (BT-DHN) (C-HA14) and preparedness and pandemic response practices (C-HA12) are the most critical factors that should be considered to increase the operational effectiveness of HAs during the pandemic. The policymakers and stakeholders will be benefitted by exploring the strength of factors in enhancing the efficiency of HAs to combat the COVID-19 endemic.

This research study has some limitations that are required to be highlighted for future similar studies to consider. The identification and finalization of factors are very challenging. The dynamic environment will develop more factors to be considered for the HOs. Thus, the study has identified sixteen critical factors that may change in future. The study has assessed the factors based on experts from one country, and thus the study may be generalized and replicated to only the developing countries that have a similar condition. The study has investigated the cause-and-effect group developed in the current study that needs to be investigated further with empirical analysis. Furthermore, various perspectives on designing and developing business models for circular economy and their integration with blockchain technology can be extended and empirically developed from the viewpoint of sustainable humanitarian systems.

Author Contributions: Conceptualization, S.J. and M.S.; methodology, S.J. and M.S.; software, M.S. and R.P.D.; formal analysis, M.S. and K.M.; investigation, M.S.; resources, K.M.; data curation, S.J. and M.S.; writing—original draft preparation, S.J., R.R. and B.E.N.; writing—review and editing, S.J., H.S. and A.M.; supervision, K.M. All authors have read and agreed to the published version of the manuscript.

Funding: The research received no external funding.

Institutional Review Board Statement: Not applicable.

Informed Consent Statement: Not applicable.

Conflicts of Interest: The authors declare no conflict of interest. 


\section{References}

1. Sharma, M.; Luthra, S.; Joshi, S.; Kumar, A. Developiforng a framework for enhancing survivability of sustainable supply chains during and post-COVID-19 pandemic. Int. J. Logist. Res. Appl. 2020, 1-21. [CrossRef]

2. Dubey, R.; Gunasekaran, A.; Bryde, D.J.; Dwivedi, Y.; Papadopoulos, T. Blockchain technology for enhancing swift-trust, collaboration and resilience within a humanitarian supply chain setting. Int. J. Prod. Res. 2020, 58, 3381-3398. [CrossRef]

3. Wagner, S.M.; Thakur-Weigold, B.; Gatti, F.; Stumpf, J. Measuring and improving the impact of humanitarian logistics consulting. Prod. Plan. Control 2021, 32, 83-103. [CrossRef]

4. Queiroz, M.M.; Fosso Wamba, S.; De Bourmont, M.; Telles, R. Blockchain adoption in operations and supply chain man-agement: Empirical evidence from an emerging economy. Int. J. Prod. Res. 2021, 59, 6087-6103. [CrossRef]

5. Dash, M.; Shadangi, P.Y.; Muduli, K.; Luhach, A.K.; Mohamed, A. Predicting the motivators of telemedicine acceptance in COVID-19 pandemic using multiple regression and ANN approach. J. Stat. Manag. Syst. 2021, 24, 319-339. [CrossRef]

6. Sahoo, K.K.; Muduli, K.K.; Luhach, A.K.; Poonia, R.C. Pandemic COVID-19: An empirical analysis of impact on Indian higher education system. J. Stat. Manag. Syst. 2021, 24, 341-355. [CrossRef]

7. Baveja, A.; Kapoor, A.; Melamed, B. Stopping Covid-19: A pandemic-management service value chain approach. Ann. Oper. Res. 2020, 289, 173-184. [CrossRef] [PubMed]

8. Bag, S.; Yadav, G.; Wood, L.C.; Dhamija, P.; Joshi, S. Industry 4.0 and the circular economy: Resource melioration in logistics. Resour. Policy 2020, 68, 101776. [CrossRef]

9. Schiffling, S.; Hannibal, C.; Fan, Y.; Tickle, M. Coopetition in temporary contexts: Examining swift trust and swift distrust in humanitarian operations. Int. J. Oper. Prod. Manag. 2020, 40, 1449-1473. [CrossRef]

10. Chou, K.P.; Prasad, M.; Lin, Y.Y.; Joshi, S.; Lin, C.-T.; Chang, J.Y. Takagi-Sugeno-Kang type collaborative fuzzy rule based system. In Proceedings of the 2014 IEEE Symposium on Computational Intelligence and Data Mining (CIDM), Orlando, FL, USA, 9-12 December 2014; pp. 315-320.

11. Zwitter, A.; Boisse-Despiaux, M. Blockchain for humanitarian action and development aid. J. Int. Humanit. Action 2018, 3, 16. [CrossRef]

12. Banomyong, R.; Varadejsatitwong, P.; Oloruntoba, R. A systematic review of humanitarian operations, humanitarian logistics and humanitarian supply chain performance literature 2005 to 2016. Ann. Oper. Res. 2019, 283, 71-86. [CrossRef]

13. Gupta, P.K.; Kumar, A.; Joshi, S. A review of knowledge, attitude, and practice towards COVID-19 with future directions and open challenges. J. Public Aff. 2020, 21, e2555. [CrossRef]

14. Joshi, S. E-Supply Chain Collaboration and Integration: Implementation Issues and Challenges. In E-Logistics and E-Supply Chain Management: Applications for Evolving Business; IGI Global: Hershey, PA, USA, 2013.

15. Joshi, R.; Joshi, S. Assessing the Readiness of Farmers towards Cold Chain Management: Evidences from India. In Designing and Implementing Global Supply Chain Management; IGI Global: Hershey, PA, USA, 2016; pp. 219-235.

16. Joshi, S. Designing and Implementing Global Supply Chain Management; IGI Global: Hershey, PA, USA, 2015.

17. Joshi, S.; Singh, R.K.; Sharma, M. Sustainable Agri-food Supply Chain Practices: Few Empirical Evidences from a Developing Economy. Glob. Bus. Rev. 2020, 0972150920907014. [CrossRef]

18. Kovács, G.; SigalaI, F. Lessons learned from humanitarian logistics to manage supply chain disruptions. J. Supply Chain Manag. 2021, 57, 41-49. [CrossRef]

19. Kusumastuti, R.D.; Arviansyah, A.; Nurmala, A.; Wibowo, S.S. Knowledge management and natural disaster preparedness: A systematic literature review and a case study of East Lombok, Indonesia. Int. J. Disaster Risk Reduct. 2021, 58, 102223. [CrossRef]

20. Ab Malik, M.H.; Omar, E.N.; Maon, S.N. Humanitarian Logistics: A Disaster Relief Operations Framework During Pandemic Covid-19 in Achieving Healthy Communities. Adv. Bus. Res. Int. J. 2020, 6, 101-113. [CrossRef]

21. Joshi, S. Social network analysis in smart tourism-driven service distribution channels: Evidence from tourism supply chain of Uttarakhand, India. Int. J. Digit. Cult. Electron. Tour. 2018, 2, 255-272. [CrossRef]

22. Joshi, S.; Sharma, M.; Kler, R. Modeling Circular Economy Dimensions in Agri-Tourism Clusters: Sustainable Performance and Future Research Directions. Int. J. Math. Eng. Manag. Sci. 2020, 5, 1046-1061. [CrossRef]

23. Yu, L.; Zhang, C.; Jiang, J.; Yang, H.; Shang, H. Reinforcement learning approach for resource allocation in humanitarian logistics. Expert Syst. Appl. 2021, 173, 114663. [CrossRef]

24. Kunz, N.; Gold, S. Sustainable humanitarian supply chain management-Exploring new theory. Int. J. Logist. Res. Appl. 2017, 20, 85-104. [CrossRef]

25. Kelman, I. COVID-19: What is the disaster? Soc. Anthropol. 2020, 28, 296-297. [CrossRef] [PubMed]

26. Seddighi, H. COVID-19 as a Natural Disaster: Focusing on Exposure and Vulnerability for Response. Disaster Med. Public Health Prep. 2020, 14, e42-e43. [CrossRef]

27. Li, J.; An, Y.; Wang, L.; Zhang, Y. Combating the COVID-19 pandemic: The role of disaster experience. Res. Int. Bus. Finance 2021, 60, 101581. [CrossRef] [PubMed]

28. Schiffling, S.; Hannibal, C.; Tickle, M.; Fan, Y. The implications of complexity for humanitarian logistics: A complex adaptive systems perspective. Ann. Oper. Res. 2020, 1-32. [CrossRef]

29. Muggy, L.; Stamm, J.L.H. Decentralized beneficiary behavior in humanitarian supply chains: Models, performance bounds, and coordination mechanisms. Ann. Oper. Res. 2019, 284, 333-365. [CrossRef] 
30. Joshi, S.; Sharma, M.; Singh, R.K. Performance Evaluation of Agro-tourism Clusters using AHP-TOPSIS. J. Oper. Strat. Plan. 2020, 3, 7-30. [CrossRef]

31. Charles, A.; Lauras, M.; Van Wassenhove, L.N.; Dupont, L. Designing an efficient humanitarian supply network. J. Oper. Manag. 2016, 47-48, 58-70. [CrossRef]

32. Queiroz, M.M.; Ivanov, D.; Dolgui, A.; Wamba, S.F. Impacts of epidemic outbreaks on supply chains: Mapping a research agenda amid the COVID-19 pandemic through a structured literature review. Ann. Oper. Res. 2020, 238, 329-354. [CrossRef]

33. Thompson, D.D.; Anderson, R. The COVID-19 response: Considerations for future humanitarian supply chain and logistics management research. J. Humanit. Logist. Supply Chain Manag. 2021, 11, 157-175. [CrossRef]

34. Kamble, S.S.; Gunasekaran, A.; Parekh, H.; Joshi, S. Modeling the internet of things adoption barriers in food retail supply chains. J. Retail. Consum. Serv. 2019, 48, 154-168. [CrossRef]

35. Ivanov, D.; Dolgui, A. Viability of intertwined supply networks: Extending the supply chain resilience angles towards survivability. A position paper motivated by COVID-19 outbreak. Int. J. Prod. Res. 2020, 58, 2904-2915. [CrossRef]

36. Joshi, S.; Sharma, M. Impact of sustainable Supply Chain Management on the Performance of SMEs during COVID-19 Pandemic: An Indian Perspective. Int. J. Logist. Econ. Glob. 2021. Available online: http://hdl.handle.net/10453/152609 (accessed on 22 December 2021).

37. Joshi, S.; Sharma, M. Prolonging retailer-supplier relationship: A study of retail firms during pandemic COVID-19. Int. J. Logist. Econ. Glob. 2021. Available online: http:/ / hdl.handle.net/10453/152610 (accessed on 22 December 2021).

38. Akhtar, P.; Marr, N.; Garnevska, E. Coordination in humanitarian relief chains: Chain coordinators. J. Humanit. Logist. Supply Chain Manag. 2012, 2, 85-103. [CrossRef]

39. Joshi, S.; Sharma, M. Digital technologies (DT) adoption in agri-food supply chains amidst COVID-19: An approach to-wards food security concerns in developing countries. J. Glob. Oper. Strateg. Source. 2021. [CrossRef]

40. Sharma, M.; Joshi, S.; Luthra, S.; Kumar, A. Managing disruptions and risks amidst COVID-19 outbreaks: Role of blockchain technology in developing resilient food supply chains. Oper. Manag. Res. 2021, 1-14. [CrossRef]

41. Shanker, S.; Barve, A.; Muduli, K.; Kumar, A.; Garza-Reyes, J.A.; Joshi, S. Enhancing resiliency of perishable product supply chains in the context of the COVID-19 outbreak. Int. J. Logist. Res. Appl. 2021, 1-25. [CrossRef]

42. Malmir, B.; Zobel, C.W. An applied approach to multi-criteria humanitarian supply chain planning for pandemic response. J. Humanit. Logistics. Supply Chain. Manag. 2021, 11, 320-346. [CrossRef]

43. Joshi, S.; Sharma, M. Social capital in the Asia Pacific: Examples from the services industry. Asia Pac. Bus. Rev. 2018, 25, 457-458. [CrossRef]

44. Tripathi, G.; Joshi, S. Creating Competitive Advantage through Sustainable Supply Chains: A Theoretical Framework for the Assessment of Practices, Dynamic Capabilities, and Enterprise Performance of Manufacturing Firms. Int. J. Recent Technol. Eng. 2019, 8, 7863-7875.

45. Ivanov, D. Lean resilience: AURA (Active Usage of Resilience Assets) framework for post-COVID-19 supply chain management. Int. J. Logist. Manag. 2021. [CrossRef]

46. Swain, S.; Peter, O.; Adimuthu, R.; Muduli, K. BlockChain Technology for Limiting the Impact of Pandemic: Challenges and Prospects. In Computational Modelling and Data Analysis in COVID-19 Research; CRC Press: Boca Raton, FL, USA, 2021; pp. 165-186.

47. Joshi, S.; Sharma, M.; Bisht, P.; Singh, S. Explaining the Factors Influencing Consumer Perception, Adoption Readiness, and Perceived Usefulness toward Digital Transactions: Online Retailing Experience of Millennials in India. J. Oper. Strat. Plan. 2021, 4, 202-223. [CrossRef]

48. Blecken, A. Humanitarian Logistics: Modelling Supply Chain Processes of Humanitarian Organizations; Haupt Verlag AG: Bern, Switzerland, 2010; p. 18.

49. Joshi, S.; Sharma, M.; Kumar, S.; Pant, M.K. Co-Creation Among Small Scale Tourism Firm: Role of Information Com-munication and Technology in Productivity and Sustainability. Int. J. Strateg. Inf. Technol. Appl. 2018, 9, 1-14. [CrossRef]

50. Joshi, S.; Sharma, M.; Rathi, S. Forecasting in Service Supply Chain Systems: A State-of-the-Art Review Using Latent Semantic Analysis. Adv. Bus. Manag. Forecast. 2017, 12, 181-212. [CrossRef]

51. Prasad, M.; Li, D.L.; Lin, C.T.; Prakash, S.; Singh, J.; Joshi, S. Designing Mamdani-Type Fuzzy Reasoning for Visualizing Prediction Problems Based on Collaborative Fuzzy Clustering. IAENG Int. J. Comput. Sci. 2015, 42.

52. Sharma, M.; Joshi, S. Barriers to blockchain adoption in health-care industry: An Indian perspective. J. Glob. Oper. Strat. Sourc. 2021, 14, 134-169. [CrossRef]

53. Polater, A. Dynamic capabilities in humanitarian supply chain management: A systematic literature review. J. Humanit. Logist. Supply Chain Manag. 2020, 11, 46-80. [CrossRef]

54. Ertem, M.A.; İşbilir, M.; Arslan, A.Ş. Review of intermodal freight transportation in humanitarian logistics. Eur. Transp. Res. Rev. 2017, 9, 10. [CrossRef]

55. Penna, P.H.V.; Santos, A.C.; Prins, C. Vehicle routing problems for last mile distribution after major disaster. J. Oper. Res. Soc. 2017, 69, 1254-1268. [CrossRef]

56. De Camargo, J.A.; Mendonça, P.S.M.; Oliveira, J.; Jabbour, C.J.C.; Jabbour, A.B.L.D.S. Giving voice to the silent: A framework for understanding stakeholders' participation in socially-oriented initiatives, community-based actions and humanitarian operations projects. Ann. Oper. Res. 2019, 283, 143-158. [CrossRef] 
57. Mannakkara, S.; Wilkinson, S.; Potangaroa, R. Resilient Post Disaster Recovery through Building Back Better; CRC Press: Boca Raton, FL, USA, 2018.

58. Lopez, A.; de Perez, E.C.; Bazo, J.; Suarez, P.; van den Hurk, B.; van Aalst, M. Bridging forecast verification and human-itarian decisions: A valuation approach for setting up action-oriented early warnings. Weather. Clim. Extrem 2020, 27, 100167. [CrossRef]

59. Rana, P.; Joshi, S. Management Practices for Sustainable Supply Chain and Its Impact on Economic Performance of SMEs: An Analytical Study of Uttarakhand State, India. Int. J. Manag. 2020, 11, 346-354.

60. Janssen, M.; Van Der Voort, H. Agile and adaptive governance in crisis response: Lessons from the COVID-19 pandemic. Int. J. Inf. Manage. 2020, 55, 102180. [CrossRef] [PubMed]

61. Dash, P.; Punia, M. Governance and disaster: Analysis of land use policy with reference to Uttarakhand flood 2013, India. Int. J. Disaster Risk Reduct. 2019, 36, 101090. [CrossRef]

62. Sharma, M.; Joshi, S. Online Advertisement Using Web Analytics Software. Int. J. Bus. Anal. 2020, 7, 13-33. [CrossRef]

63. Sigala, I.F.; Kettinger, W.J.; Wakolbinger, T. Digitizing the field: Designing ERP systems for Triple-A humanitarian supply chains. J. Humanit. Logist. Supply Chain Manag. 2020, 10, 231-260. [CrossRef]

64. Gavidia, J.V. A model for enterprise resource planning in emergency humanitarian logistics. J. Humanit. Logist. Supply Chain Manag. 2017, 7, 246-265. [CrossRef]

65. Sharma, M.; Joshi, S. Digital supplier selection reinforcing supply chain quality management systems to enhance firm's performance. TQM J. 2020. [CrossRef]

66. Goniewicz, K.; Khorram-Manesh, A.; Hertelendy, A.J.; Goniewicz, M.; Naylor, K.; Burkle, F.M., Jr. Current Response and Management Decisions of the European Union to the COVID-19 Outbreak: A Review. Sustainability 2020, 12, 3838. [CrossRef]

67. Sharma, M.; Joshi, S.; Govindan, K. Issues and solutions of electronic waste urban mining for circular economy transition: An Indian context. J. Environ. Manag. 2021, 290, 112373. [CrossRef]

68. Meier, P. Digital Humanitarians: How Big Data is Changing the Face of Humanitarian Response; CRC Press: Boca Raton, FL, USA, 2015.

69. Sharma, M.; Joshi, S.; Kumar, A. Assessing enablers of e-waste management in circular economy using DEMATEL method: An Indian perspective. Environ. Sci. Pollut. Res. 2020, 27, 13325-13338. [CrossRef]

70. Gupta, S.; Altay, N.; Luo, Z. Big data in humanitarian supply chain management: A review and further research directions. Ann. Oper. Res. 2019, 283, 1153-1173. [CrossRef]

71. Sharma, M.; Joshi, S.; Luthra, S.; Kumar, A. Analysing the Impact of Sustainable Human Resource Management Practices and Industry 4.0 Technologies Adoption on Employability Skills. Int. J. Manpow. 2021. Available online: http://repository.londonmet. ac.uk/6738/ (accessed on 16 December 2021).

72. Sharma, M.; Luthra, S.; Joshi, S.; Kumar, A. Implementing challenges of artificial intelligence: Evidence from public manufacturing sector of an emerging economy. Gov. Inf. Q. 2021, 101624. [CrossRef]

73. Hart, O.E.; Halden, R.U. Modeling wastewater temperature and attenuation of sewage-borne biomarkers globally. Water Res. 2020, 172, 115473. [CrossRef] [PubMed]

74. Sharma, M.; Luthra, S.; Joshi, S.; Kumar, A. Accelerating retail supply chain performance against pandemic disruption: Adopting resilient strategies to mitigate the long-term effects. J. Enterp. Inf. Manag. 2021, 34, 1844-1873. [CrossRef]

75. Ishiwatari, M.; Koike, T.; Hiroki, K.; Toda, T.; Katsube, T. Managing disasters amid COVID-19 pandemic: Approaches of response to flood disasters. Prog. Disaster Sci. 2020, 6, 100096. [CrossRef]

76. Singh, R.K.; Joshi, S.; Sharma, M. Modelling Supply Chain Flexibility in the Indian Personal Hygiene Industry: An ISM-Fuzzy MICMAC Approach. Glob. Bus. Rev. 2020, 0972150920923075. [CrossRef]

77. Bhattacharya, S.; Hasija, S.; Van Wassenhove, L.N. Designing Efficient Infrastructural Investment and Asset Transfer Mechanisms in Humanitarian Supply Chains. Prod. Oper. Manag. 2014, 23, 1511-1521. [CrossRef]

78. Altay, N.; Narayanan, A. Forecasting in humanitarian operations: Literature review and research needs. Int. J. Forecast. 2020. [CrossRef]

79. Biswal, J.N.; Muduli, K.; Satapathy, S. Critical Analysis of Drivers and Barriers of Sustainable Supply Chain Management in Indian Thermal Sector. Int. J. Procure. Manag. 2017, 10, 411-430. [CrossRef]

80. Altay, N.; Kovács, G.; Spens, K. The evolution of humanitarian logistics as a discipline through a crystal ball. J. Humanit. Logist. Supply Chain Manag. 2021, 11, 577-584. [CrossRef]

81. Peter, O.; Swain, S.; Muduli, K.; Ramasamy, A. IoT in Combating Covid 19 Pandemics: Lessons for Developing Countries, Assessing COVID-19 and Other Pandemics and Epidemics using Computational Modelling and Data Analysis; Springer: Berlin/Heidelberg, Germany, 2021; pp. 113-132.

82. Sharma, M.; Joshi, S. Brand sustainability among young consumers: An AHP-TOPSIS approach. Young Consum. 2019, 20, 314-337. [CrossRef]

83. Muduli, K.; Barve, A. Analysis of critical activities for GSCM implementation in mining supply chains in India using fuzzy analytical hierarchy process. Int. J. Bus. Excel. 2015, 8, 767. [CrossRef]

84. Sharma, M.; Joshi, S.; Kannan, D.; Govindan, K.; Singh, R.; Purohit, H.C. Internet of Things (IoT) adoption barriers of smart cities' waste management: An Indian context. J. Clean. Prod. 2020, 270, 122047. [CrossRef]

85. Seker, S.; Zavadskas, E.K. Application of Fuzzy DEMATEL Method for Analyzing Occupational Risks on Construction Sites. Sustainability 2017, 9, 2083. [CrossRef] 
86. Prakash, S.; Joshi, S.; Bhatia, T.; Sharma, S.; Samadhiya, D.; Shah, R.R.; Kaiwartya, O.; Prasad, M. Characteristic of enterprise collaboration system and its implementation issues in business management. Int. J. Bus. Intell. Data Min. 2020, 16, 49. [CrossRef]

87. Kannan, G.; Muduli, K.; Devika, K.; Barve, A. Investigation of influential strength of factors on GSCM adoption in mining in-dustries operating in India. Resour. Conserv. Recycl. 2016, 107, 185-194.

88. Brem, A.; Viardot, E.; Nylund, P.A. Implications of the coronavirus (COVID-19) outbreak for innovation: Which technologies will improve our lives? Technol. Forecast. Soc. Change 2021, 163, 120451. [CrossRef]

89. Fernandez-Luque, L.; Imran, M. Humanitarian health computing using artificial intelligence and social media: A narrative literature review. Int. J. Med. Inform. 2018, 114, 136-142. [CrossRef]

90. Quarshie, A.M.; Leuschner, R. Interorganizational Interaction in Disaster Response Networks: A Government Perspective. J. Supply Chain Manag. 2020, 56, 3-25. [CrossRef]

91. Centobelli, P.; Cerchione, R.; Del Vecchio, P.; Oropallo, E.; Secundo, G. Blockchain technology for bridging trust, traceability and transparency in circular supply chain. Inf. Manag. 2021, 103508. [CrossRef]

92. Centobelli, P.; Cerchione, R.; Del Vecchio, P.; Oropallo, E.; Secundo, G. Blockchain technology design in accounting: Game changer to tackle fraud or technological fairy tale? Account. Audit. Account. J. 2021. [CrossRef] 